\title{
An assessment of the air quality in apple warehouses: new records of Aspergillus europaeus, Aspergillus pulverulentus, Penicillium allii and Penicillium sumatraense as decay agents
}

\author{
Marwa Smiri ${ }^{1}$ - Amina Kheireddine ${ }^{1} \cdot$ Rania Hammami $^{1} \cdot$ Mustapha Rouissi $^{2} \cdot$ Eduardo Antonio Espeso $^{3}$. \\ Najla Sadfi-Zouaoui ${ }^{1}$ (D)
}

Received: 24 January 2021 / Revised: 19 August 2021 / Accepted: 22 August 2021

(c) The Author(s), under exclusive licence to Springer-Verlag GmbH Germany, part of Springer Nature 2021

\begin{abstract}
Airborne fungi are one of the major components of aeromycobiota known to produce several fungal diseases in fruits. Their presence in indoor environment of warehouses may limit the storage period of apples. Qualitative and quantitative analyses of airborne fungal spores were conducted using gravity settling techniques to detect fungal airspora present in the atmosphere of two apple warehouses in Tunisia. In this study, 375 fungal isolates were obtained and purified. Phylogenetic analysis of calmodulin, beta-tubulin and ITS regions coupled with phenotypic characterization helped to identify 15 fungal species. Penicillium exhibited the highest diversity with ten species detected (Penicillium allii, P. chrysogenum, P. citrinum, P. expansum, $P$. italicum, $P$. polonicum, $P$. solitum, $P$. steckii, $P$. sumatraense and $P$. viridicatum), followed by four species of Aspergillus genus (Aspergillus europaeus, A. flavus, A. niger and A. pulverulentus) and Alternaria alternata. In vivo experiments confirmed the pathogenicity of 13 species at room temperature and under cold-storage conditions. Among them, $A$. europaeus, A. pulverulentus, $P$. allii and $P$. sumatraense were described for the first time as pathogens on apples. The present study identified the major airborne fungi associated with postharvest rot in apple storage facilities in Tunisia and may help in efficient control of postharvest and storage fruit diseases.
\end{abstract}

Keywords Postharvest disease $\cdot$ Cold rooms $\cdot$ Pathogenicity $\cdot$ Airspora $\cdot$ Fungi

\section{Introduction}

Postharvest fungal diseases are one of the significant factors that limit the shelf life of fruits (Iqbal et al. 2019; Zhang et al. 2019) by altering their organoleptic characteristics. Despite the use of improved storage technologies and plant protection products, fruit losses including apples

Communicated by Olaf Kniemeyer.

Najla Sadfi-Zouaoui najla.sadfi@fst.utm.tn

1 Laboratoire de Mycologie, Pathologies et Biomarqueurs (LR16ES05), Département de Biologie, Université de TunisEl Manar, 2092 Tunis, Tunisia

2 Institut National de la Recherche Agronomique de Tunisie, 1004 Tunis, Tunisia

3 Departamento de Microbiología Molecular, Centro de Investigaciones Biologicas del Consejo Superior de Investigaciones Científicas, 28006 Madrid, Spain are estimated to range up to $20-25 \%$ per year in developed countries (Nabi et al. 2017) but more severe in developing countries (Singh et al. 2017).

In Tunisia, apples are among the most produced and consumed fruits (ONAGRI 2018). Its production has increased from 98.300 tons in 2017 to 139.500 tons in 2018, which is an increase of $41 \%$ (GIFRUITS 2018). The governorate of Kasserine is considered as the most apple-producing region with 3 million apple trees followed by Siliana (30,150 tons) and greater Tunis (14,352 tons). The preservation of fruits in Tunisia depends heavily on the cold-storage industry. In fact, the agricultural sector holds more than $70 \%$ of the total refrigerated storage capacities, approximately $1100 \mathrm{~m}^{3}$ are maintained to store fruits and vegetables.

Apple storage stations in Tunisia have reported significant losses in fruit quantity (Gara et al. 2019).

These losses are due to the occurrence of postharvest fungal diseases (Bahri et al. 2019). Postharvest diseases of apple are caused by a range of fungal pathogens (Sutton 2014). The most common and destructive postharvest 
disease of stored apples is the blue mold caused by Penicillium expansum (Spotts et al. 1999; Spadaro et al. 2010; Yu et al. 2014; da Rocha Neto et al. 2016; Darolt et al. 2016). Several other species such as P. solitum (Sholberg et al. 2005), Penicillium griseofulvum (Spadaro et al. 2011), Penicillium carneum (Peter et al. 2012), P. crustosum (Vico et al. 2014a,b), Penicillium biourgeianum (Azam et al. 2016) and P. chrysogenum (Rharmitt et al. 2016) have also been reported to be responsible for the rot.

Infected apples develop several other forms of rot such as Alternaria Rot caused by Alternaria alternata (Shtienberg 2012; Zhu et al. 2017), rot caused by Aspergillus niger and A. flavus (Hasan 2000a,b), grey mold by Botrytis cinerea (Romanazzi and Feliziani 2014), Bitter rot by Colletotrichum acutatum (Mari et al. 2012) and Bull's eye rot by Neofabraea avagabunda (Di Francesco et al. 2019). Wounds caused by insects and birds, as well as by physical damage occurring before or during harvest, are important entrance sites for pathogens (Wenneker and Thomma 2020). It has been reported that storage sites may represent a "reservoir" of airborne fungi (O'Gorman and Fuller 2008). These airborne fungi can cause devastating losses (Lucas et al. 1992). In addition, Fungi may produce mycotoxins such as patulin and trichothecenes in infected fruit and it may persist even if they are no longer present in food (Fernández-Cruz et al. 2010). Exposure to theses toxins pose health risk for consumers due to their properties to induce severe toxicity effects at low dose levels (Agriopoulou et al. 2020).

Since several fungal species can be responsible for apple decay, the detection and an accurate identification of pathogens represent a preliminary step to take to control postharvest disease. Conventional methods for fungal identification involve the examination of morphological characteristics on standardized media such as color and texture of colonies, growth rate and size of colonies and microscopic structures. Phenotypic characterization may be influenced by various environmental factors such as temperature, humidity and oxygen level (Tiwari et al. 2011) leading to misidentification of the isolates.

Nowadays, fungal pathogens are identified using molecular methods alongside morphological characterization. The internal transcribed spacer rDNA sequence (ITS) is the most widely sequenced marker for fungi. Universal primers are available, and it is the official sequence for barcoding (Schoch et al. 2012). Different gene regions have been also used and showed potential to make a clear distinction between closely related fungal species such as calmodulin (CaM) and beta-tubulin (benA) (Samson et al. 2014; Visagie et al. 2014).

A comprehensive research on the diversity and pathogenicity of airspora associated with stored apple is needed to develop efficient control of fungal disease in storage units.
However, there is a lack of information about the airspora profile in indoor warehouses of apple in Tunisia.

Therefore, the aim of this study was to investigate the predominant of airborne fungi occupying the atmosphere of two cold-storage stations of apples in Tunisia, and to identify the obtained airspora using phenotypic and molecular tools and study their pathogenicity.

\section{Materials and methods}

\section{Sample collection}

Sample collection was undertaken from two cold-storage facilities of apples located in Ben Arous, Tunisia for 3 months (December 2016, February and April 2017). Station 1 (S1) and station 2 (S2) had three and seven refrigerated rooms, respectively. Airborne fungi were isolated using a calibrated impaction sampler MAS-100 Eco ${ }^{\circledR}$ (MBV, Switzerland). The MAS-100 Eco ${ }^{\circledR}$ was mounted in the center of each room, approximately $1 \mathrm{~m}$ from the floor. Two agar plates were taken from each room and the viable particles were impacted on the surface of potato dextrose agar plates, amended with chloramphenicol. Samples were carried to the laboratory and incubated at $25^{\circ} \mathrm{C}$ for 7 days (Despot and Klaric 2014). Fungal colonies were counted and converted to $\mathrm{CFU} / \mathrm{m}^{3}$ using Feller's formula given by the manufacturer (MBV, Switzerland):

$(\operatorname{Pr}=N 1 / N+1 / N-1+1 / N-2+1 / N-r+1)$,

where Pr is the probable statistical total; $r$ is the Number of CFU counted; $N$ is the total number of holes in the sampling head.

\section{Isolates grouping and selection of representative isolates}

Since the number of isolates were large, fungi were grouped based upon their micro- and macro-morphological characteristics using standard taxonomic keys (Dugan 2006; Johnston 2008). Each group was assigned a number and a representative isolate was randomly chosen for molecular analysis.

\section{Morphological identification}

Spore suspension were made with a solution containing $0.2 \%$ agar and $0.05 \%$ tween 80 solution as recommended by Visagie et al. (2014) to obtain monosporic colonies. Macroscopic characteristics were studied on Czapek yeast autolysate agar (CYA), yeast extract sucrose agar (YES), malt extract agar (MEA) and potato dextrose agar (PDA) media (Rotem 1994; Samson et al. 2014; Visagie et al. 2014). The 
studied characteristics were the colony size, colony color and texture. Microscopic observations were made from 7 to 10 days cultures grown on MEA media using light microscope (Leica).

\section{DNA extraction}

The genomic DNA was extracted from 7-day-old fungal cultures grown in culture plates. Using a sterilized scalpel, a piece of mycelia was transferred to a $1.5 \mathrm{~mL}$ Eppendorf tube containing $500 \mu \mathrm{L}$ of lysis buffer $(400 \mathrm{mM}$ Tris- $\mathrm{HCl}$ [pH 8.0], $60 \mathrm{mM}$ EDTA [pH 8.0], $150 \mathrm{mM} \mathrm{NaCl}, 1 \%$ sodium dodecyl sulfate). The tube was then maintained at room temperature for $10 \mathrm{~min}$. After adding $150 \mu \mathrm{L}$ of potassium acetate buffer $(\mathrm{pH} 4.8 ; 60 \mathrm{~mL}$ of $5 \mathrm{M}$ potassium acetate, $11.5 \mathrm{~mL}$ of glacial acetic acid and $28.5 \mathrm{~mL}$ of distilled water), the tube was vortexed for $10 \mathrm{~min}$. and spun at $12,000 \mathrm{rpm}$ for $2 \mathrm{~min}$. and $11,000 \mathrm{rpm}$ for $5 \mathrm{~min}$. The supernatant was transferred to another Eppendorf tube and centrifuged again at 12,000 rpm for $2 \mathrm{~min}$. An equal volume of isopropanol was added to the supernatant, recovered and mixed together by inversion. After centrifuging at 12,000 for $2 \mathrm{~min}$, the DNA pellet was washed in $300 \mu \mathrm{L}$ of $70 \%$ ethanol and spun at 12,000 rpm for $2 \mathrm{~min}$. After removing the supernatant, the DNA pellet was air dried and dissolved in $50 \mu \mathrm{L}$ of $1 \times$ Tris-EDTA (Liu et al. 2000).

\section{PCR amplifications}

Calmodulin (Cam), beta-tubulin ( $\beta$-tub) genes were targeted to design a specific primer set for isolates belonging to Penicillium (PCAM 1, 5'-AGGACAAGGATGGCGATGG-3'; PCAM 2, 5'-TCGTCGGTCAGCTTCTC-3') and Aspergillus (ABEN 1, 5'-AGTCCGGTGCTGGTAACAACTGG-3'; ABEN 2, 5'-TCCTGGTACTGCTGGTACTCG-3'), respectively, using Vector NTI software.

These primers generated amplicon lengths of $\approx 500$ and $\approx 900 \mathrm{bp}$. Specificity tests were conducted amplifying DNA from different fungal genera commonly associated with apple decay. All PCR amplifications were performed in a total reaction volume of $50 \mathrm{~mL}$ consisting of $1 \mu \mathrm{L}$ DNA template, $5 \mu \mathrm{L}$ of $10 \times \mathrm{PCR}$ buffer, $1.5 \mathrm{~mL}$ of $50 \mathrm{mM} \mathrm{MgCl}_{2}$, $1 \mu \mathrm{L}$ of dNTP (2.5 mM each), $3 \mu \mathrm{L}$ of each primer, $1 \mu \mathrm{L}$ of Taq DNA Polymerase and $34.5 \mu \mathrm{L}$ of $\mathrm{H}_{2} \mathrm{O}$. The PCR cycle condition was performed in a thermal cycler (Biometra, Germany) with an initial denaturation step for $2 \mathrm{~min}$ at $92{ }^{\circ} \mathrm{C}$, followed by 25 cycles ( 1 cycle consisting of denaturation for $30 \mathrm{~s}$ at $92{ }^{\circ} \mathrm{C}$, annealing for $30 \mathrm{~min}$ at $57^{\circ} \mathrm{C}$ and extension for 1 min at $72{ }^{\circ} \mathrm{C}$ ), with a final extension of 10 min at $72^{\circ} \mathrm{C}$. An Internal Transcribed Spacer (ITS) gene was used to identify isolates belonging to Alternaria genus using universal primers ITS4 and ITS5 (White et al. 1990). The same PCR mix described previously was also used. Template DNA was initially denatured for $2 \mathrm{~min}$ at $94{ }^{\circ} \mathrm{C}$ followed by 25 cycles of amplification. Each cycle consisted of denaturation for $30 \mathrm{~s}$ at $94{ }^{\circ} \mathrm{C}$, primer annealing for $30 \mathrm{~s}$ at $56{ }^{\circ} \mathrm{C}$ and extension for $1 \mathrm{~min}$ at $72{ }^{\circ} \mathrm{C}$. The last cycle was followed by a final extension at $72{ }^{\circ} \mathrm{C}$ for $10 \mathrm{~min}$. Amplicons were subjected to electrophoresis in $0.8 \%$ agarose gels.

\section{Sequencing and phylogenetic analysis}

The PCR products were purified using a PCR purification column (Macherey-Nagel) and sent for sequencing. The sequences of each gene (i.e., Cam, $\beta$-tub and ITS) were, firstly, compared using the BLAST program (http://www. ncbi.nlm.nih.gov/BLAST/) and they were deposited in the GenBank. Then, phylogenetic trees topology was inferred by the maximum likelihood, neighbor-joining, and maximumparsimony method using MEGA v7.0 (Kumar et al. 2016) with bootstrap values based on 1000 replications. Aspergillus flavus and $P$. expansum were used as outgroups.

\section{Pathogenicity tests}

To verify the pathogenicity potential of detected isolates, three mature healthy apples (cv. Golden delicious) with uniform size and without physical injuries were used to perform a pathogenicity test as described by Louw and Korsten (2014). All fungal isolates were grown on MEA for 7 days at $25{ }^{\circ} \mathrm{C}$. Conidia were scraped from the culture and spore concentration was adjusted to $10^{5}$ spores $/ \mathrm{mL}$. Apples were disinfected for two min in $2 \%$ sodium hypochloride solution, sterilized with $70 \%$ alcohol and rinsed three times with sterile distilled water. Next, two apples were wound-inoculated with $20 \mu \mathrm{L}$ of conidial suspension on three sides per isolates and were placed on wet paper towels in plastic containers sealed with parafilm. Control fruit were inoculated with sterile distilled water and all the boxes were stored at $25^{\circ} \mathrm{C}$ for 7 days in the darkness. All experiments were repeated three times.

\section{Cold-storage trials}

To describe pathogen behavior under storage conditions, mature healthy apples (cv. Golden delicious) were surface disinfested with $70^{\circ}$ alcohol and then gently wounded with a sterile micropipette tips on three sides. A spore suspension $\left(10^{5}\right.$ conidia $\left./ \mathrm{mL}\right)$, from each isolate, was prepared from 10-day-old culture then inoculated to apples while, controls were inoculated with sterile distilled water. Three replicates were put in sealed container and incubated under refrigerated conditions $\left(2 \pm 1.7{ }^{\circ} \mathrm{C}\right)$ for 43 days in the dark. All the experiments were repeated three times. During the incubation period, the lesion diameters were recorded every second 
day starting from the third day after inoculation as described by Louw and Korsten (2014).

\section{Statistical analysis}

SPSS program v21 was used for descriptive statistics. Concentrations of airborne fungi are represented as mean $\pm \mathrm{SD}$ of $\mathrm{CFU} / \mathrm{m}^{3}$. The likelihood of statistically significant differences between the concentrations of airborne fungi measured in each sampling was assessed by one-way analysis of variance (ANOVA). Mean comparison of lesion diameter at storage conditions generated by 15 species was estimated according to Duncan test. Statistical significance was set at 0.001 . Pathogenicity trials were conducted with two replications under a complete factorial design with two factors (species and incubation time).

\section{Results}

\section{Fungal concentration}

The study showed that fungal spores were present throughout the storage period in all sampled cold rooms in both stations. Concentrations of airborne fungi in $\mathrm{CFU} / \mathrm{m}^{3}$ found in both stations during three months of sampling are listed in Table 1.

In this study, the maximum measured concentration was $2228 \mathrm{CFU} / \mathrm{m}^{3}$ and the lowest was $23.67 \mathrm{CFU} / \mathrm{m}^{3}$.

In $\mathrm{S} 1$, the highest spore incidence $\left(847.16 \mathrm{CFU} / \mathrm{m}^{3}\right)$ was recorded in $\mathrm{N} 7$ followed by $\mathrm{N} 5\left(643.5 \mathrm{CFU} / \mathrm{m}^{3}\right)$ and $\mathrm{N} 4$ $\left(563.33 \mathrm{CFU} / \mathrm{m}^{3}\right)$. For S2, SF3 holds the lowest airborne fungal concentration with an average of $36.6 \mathrm{CFU} / \mathrm{m}^{3}$ followed by SF1 with $121.33 \mathrm{CFU} / \mathrm{m}^{3}$. As indicated in Fig. 1 . Spore concentration in the atmosphere of all the sites peaked

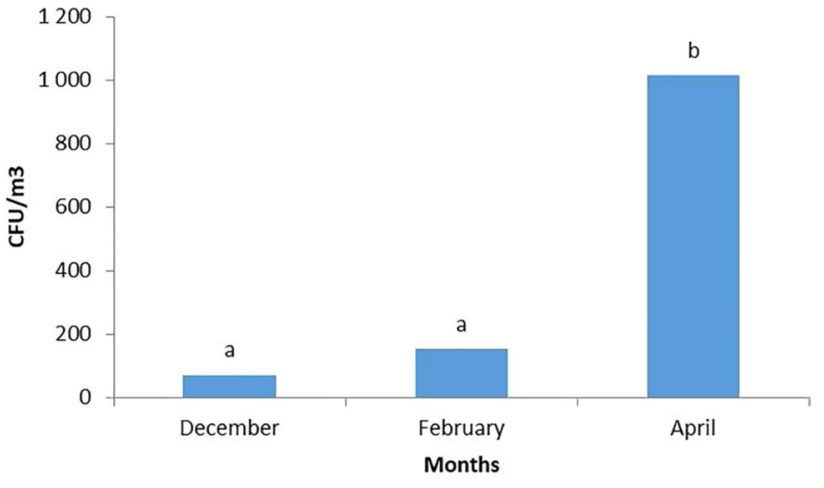

Fig. 1 Concentration of total airborne fungi in CFU $/ \mathrm{m}^{3}$ measured during 3 months of sampling in two apple storage facilities in Tunisia using MAS-100Eco ${ }^{\circledR}$ air monitoring system in S1. Letters that are dissimilar are significantly different $(a, b)$

during the third month. Levels of airborne fungi in April were significantly higher than the first 2 months $(p<0.001)$ reaching 1071.14 and $177.33 \mathrm{CFU} / \mathrm{m}^{3}$ for $\mathrm{S} 1$ and $\mathrm{S} 2$, respectively (Fig. 2).

\section{Phenotypic characterization of collected airspora}

Based on morphological features, 375 colonies were obtained from both locations. The obtained isolates were grouped into 21 morphologically similar groups. According to cultural and morphological characteristics, Penicillium, Aspergillus and Alternaria isolates presented 15, 4 and 2 different groups, respectively (Table 2).

The morphological characterization of representative isolates selected for identification is presented in Tables 3 and 4. In CYA, the diameter of the colonies ranged between 25 and $3 \mathrm{~mm}$ for Penicillium spp. and 35-65 $\mathrm{mm}$ for Aspergillus spp. Conidia of all examined penicillia were colored
Table 1 Mean total fungal spore concentration $\left(\mathrm{CFU} / \mathrm{m}^{3}\right)$ measured at two apple's storage stations in Tunisia

\begin{tabular}{|c|c|c|c|c|c|}
\hline Station & Room & December & February & April & Total $\left(\mathrm{CFU} / \mathrm{m}^{3}\right)$ \\
\hline \multirow[t]{7}{*}{ Station 1} & Room N1 & $60.5 \pm 6.36$ & $404 \pm 67.9$ & $287 \pm 4.24$ & 250 \\
\hline & Room N2 & $50.5 \pm 7.78$ & $78.5 \pm 9.19$ & $303 \pm 18.38$ & 144 \\
\hline & Room N3 & $117.5 \pm 7.78$ & $50.5 \pm 0.7$ & $906.5 \pm 833.68$ & 358 \\
\hline & Room N4 & $19.5 \pm 6.36$ & $280 \pm 7.07$ & $1390.5 \pm 1184.4$ & 563 \\
\hline & Room N5 & $66.5 \pm 9.19$ & $72 \pm 9.9$ & $1792 \pm 616.6$ & 643 \\
\hline & Room N6 & $44 \pm 4.24$ & $78.5 \pm 12.02$ & $583 \pm 149.9$ & 235 \\
\hline & Room N7 & $157 \pm 9.9$ & $156.5 \pm 7.78$ & $2228 \pm 0$ & 847 \\
\hline \multirow[t]{3}{*}{ Station 2} & Room SF1 & $32 \pm 3.6$ & $42.33 \pm 2.51$ & $289.7 \pm 6.11$ & 121 \\
\hline & Rom SF2 & $124.67 \pm 5.69$ & $166.67 \pm 4.93$ & $182.33 \pm 12.22$ & 157 \\
\hline & Room SF3 & $23.67 \pm 1.15$ & $26 \pm 2.64$ & $60 \pm 6.56$ & 36 \\
\hline
\end{tabular}

$[\mathrm{Mean} \pm \mathrm{SD}]$; all numbers are positive-hole transformed to account for multiple depositions of particles at single impaction sites

N1-N7, 7 refrigerated rooms sampled belonging to station 1; SF1-SF3, 3 refrigerated rooms sampled belonging to station 2 


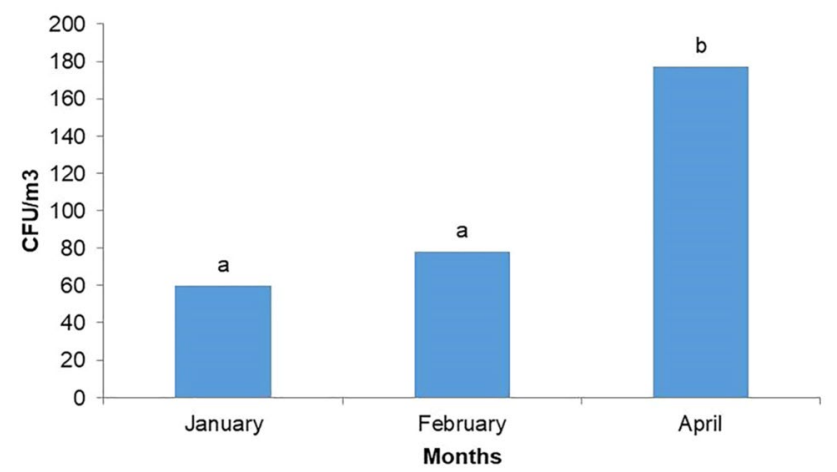

Fig. 2 Concentration of total airborne fungi in $\mathrm{CFU} / \mathrm{m}^{3}$ measured during 3 months of sampling in two apple storage facilities in Tunisia using MAS-100Eco ${ }^{\circledR}$ air monitoring system in S2. Letters that are dissimilar are significantly different $(a, b)$

Table 2 Frequency of fungal genera and groups selected for identification

\begin{tabular}{lccc}
\hline Fugal genera & $\begin{array}{l}\text { Number of } \\
\text { isolates }\end{array}$ & Frequency (\%) & $\begin{array}{l}\text { Pheno- } \\
\text { typic } \\
\text { groups }\end{array}$ \\
\hline Penicillium spp. & 288 & 76.8 & 15 \\
Aspergillus spp. & 54 & 14.4 & 4 \\
Alternaria spp. & 21 & 5.6 & 2 \\
Other fungi & 12 & 3.2 & - \\
Total & 375 & 100 & 21 \\
\hline
\end{tabular}

in shades of grey-green, blue-green or dull green. In the other hand, Aspergillus isolates produced yellowish to grey, green or well-marked black conidia (Table 4). After
1 week of incubation at $25{ }^{\circ} \mathrm{C}$, Sporulation of Penicillium isolates were observed on YES. Thirteen samples have a strong sporulation on more than $90 \%$ of the colony. C5B1 and C7A29 presented a moderate sporulation; only in the center of the colony. MEA provided the growth of isolates with different colony textures. In this survey, Penicillium sp. presented velutinous, fasciculate and floccose colony texture. Color of conidium varied between green, grey-green, blue-green or dull green. Aspergillus spp. presented only velutinous and floccose colonies with diameters ranged between 24 and $56 \mathrm{~mm}$. Microscopic examination showed that the conidiophores of Penicillium isolates were one-stage branched (biverticillate) or two-stage branched (terverticillate) with metula length between 7.1 and $14 \mu \mathrm{m}$. Examined Conidia presented nearby diameters $(2.3-3.7 \mu \mathrm{m})$ and were smooth walled except two isolates (S8 and D2) that were finely rough (Table 3). All of Aspergillus isolates had biseriate conidial heads. Conidia observed ranged between 3.5 and $4.7 \mu \mathrm{m}$. Ornamentation of spores was rough in C7A16 and C6B6 echinulate in C7A13 and verruculose in C5B26 (Table 4). On PDA, Alternaria isolates presented olivaceous black and black colonies. Conidiophores were branched and conidia were formed in long ovoid chains.

\section{Molecular identification and phylogenetic analysis}

Partial amplification of Cam and $\beta$-tub was successful in all tested isolates and yielded a single amplicon band of approximately 500 and $900 \mathrm{bp}$ in gel electrophoresis, respectively. Each primer set (PCAM 1-PCAM 2) and (ABEN 1-ABEN 2) were only able to amplify isolates belonging to Penicillium and Aspergillus genus, respectively, thus confirming

Table 3 Morphological characterization of Penicillium groups detected in indoor air of storage facilities

\begin{tabular}{|c|c|c|c|c|c|c|c|c|}
\hline Group & Isolate code & CYA & YES & MEA & Phialide & Conidia & Metula & Branching pattern \\
\hline 1 & C7B20 & $38 \mathrm{~mm}$, dull green & Strong & Fasiculate, grey-green & $9.7 \mu \mathrm{m}$ & $3.7 \mu \mathrm{m}$, smooth & $11.8 \mu \mathrm{m}$ & Ter-verticillate \\
\hline 2 & $\mathrm{C} 5 \mathrm{~B} 1$ & $40 \mathrm{~mm}$, grey-green & Moderate & Velutinous, grey-green & $10 \mu \mathrm{m}$ & $2.7 \mu \mathrm{m}$, smooth & $8.1 \mu \mathrm{m}$ & Bi-verticillate \\
\hline 3 & $\mathrm{C} 1 \mathrm{~A} 25$ & $30 \mathrm{~mm}$, dull green & Strong & Fasiculate, grey-green & $6 \mu \mathrm{m}$ & $2.5 \mu \mathrm{m}$, smooth & $11.5 \mu \mathrm{m}$ & Ter-verticillate \\
\hline 4 & $\mathrm{C} 4 \mathrm{~A} 4$ & $39 \mathrm{~mm}$, blue-green & Strong & Floccose, green & $7.7 \mu \mathrm{m}$ & $2.4 \mu \mathrm{m}$, smooth & $10 \mu \mathrm{m}$ & Ter-verticillate \\
\hline 5 & C5A10 & $50 \mathrm{~mm}$, grey-green & Strong & Velutinous, green & $10.9 \mu \mathrm{m}$ & $4.9 \mu \mathrm{m}$, smooth & $12.4 \mu \mathrm{m}$ & Ter-verticillate \\
\hline 6 & C6A1 & $30 \mathrm{~mm}$, dark-green & Strong & Velutinous, blue-green & $8.1 \mu \mathrm{m}$ & $2.9 \mu \mathrm{m}$, smooth & $9.2 \mu \mathrm{m}$ & Bi-verticillate \\
\hline 7 & $\mathrm{C} 2 \mathrm{~B} 12$ & $52 \mathrm{~mm}$, green & Strong & Floccose, green & $7.7 \mu \mathrm{m}$ & $2.3 \mu \mathrm{m}$, smooth & $14 \mu \mathrm{m}$ & Ter-verticillate \\
\hline 8 & $\mathrm{D} 2$ & $40 \mathrm{~mm}$, Pure green & Strong & Velutinous, green & $8.3 \mu \mathrm{m}$ & $2.9 \mu \mathrm{m}$, finely rough & $12.8 \mu \mathrm{m}$ & Ter-verticillate \\
\hline 9 & $\mathrm{C} 2 \mathrm{~A} 8$ & $38 \mathrm{~mm}$, blue-green & Strong & Velutinous, blue-green & $8.9 \mu \mathrm{m}$ & $3.7 \mu \mathrm{m}$, smooth & $11.9 \mu \mathrm{m}$ & Ter-verticillate \\
\hline 10 & C7A25 & $30 \mathrm{~mm}$, dull green & Strong & Velutinous, blue-green & $8 \mu \mathrm{m}$ & $3.3 \mu \mathrm{m}$, smooth & $10.9 \mu \mathrm{m}$ & Ter-verticillate \\
\hline 11 & S7 & $38 \mathrm{~mm}$, blue-green & Strong & Velutinous, blue-green & $6.4 \mu \mathrm{m}$ & $2.2 \mu \mathrm{m}$, smooth & $7.8 \mu \mathrm{m}$ & Bi-verticillate \\
\hline 12 & C7A29 & $27 \mathrm{~mm}$, blue-green & Moderate & Velutinous, blue-green & $9 \mu \mathrm{m}$ & $3.5 \mu \mathrm{m}$, smooth & $11.6 \mu \mathrm{m}$ & Ter-verticillate \\
\hline 13 & C4A1 & $25 \mathrm{~mm}$, grey-green & Strong & Velutinous, dull green & $8.2 \mu \mathrm{m}$ & $2.4 \mu \mathrm{m}$, smooth & $7.1 \mu \mathrm{m}$ & Bi-verticillate \\
\hline 14 & S8 & $18 \mathrm{~mm}$, green & Strong & Velutinous, green & $8.2 \mu \mathrm{m}$ & $2.8 \mu \mathrm{m}$, smooth & $12.6 \mu \mathrm{m}$ & Ter-verticillate \\
\hline 15 & C7A1 & $24 \mathrm{~mm}$, green & Strong & Fasiculate, green & $7.8 \mu \mathrm{m}$ & $2.3 \mu \mathrm{m}$, smooth & $14 \mu \mathrm{m}$ & Ter-verticillate \\
\hline
\end{tabular}

CYA colony diameter, color of conidium; YES degree of sporulation; MEA colony texture, color of conidium 
Table 4 Morphological characterization of Aspergillus groups detected in indoor air of apple storage facilities

\begin{tabular}{llllll}
\hline Group & Isolate code & CYA & MEA & Conidia & Vesicles \\
\hline 1A & C7A16 & $35 \mathrm{~mm}$, yellow-grey & $24 \mathrm{~mm}$, floccose & $4.5 \mu \mathrm{m}$, rough & Biseriate \\
2B & C7A13 & $58 \mathrm{~mm}$, yellow-green & $56 \mathrm{~mm}$, velutinous & $3.5 \mu \mathrm{m}$, echinulate & Biseriate \\
3C & C6B6 & $65 \mathrm{~mm}$, dark brown & $50 \mathrm{~mm}$, velutinous & $4 \mu \mathrm{m}$, rough & Biseriate \\
4D & C5B26 & $63 \mathrm{~mm}$, dark brown & $49 \mathrm{~mm}$, velutinous & $4.7 \mu \mathrm{m}$, verruculose & Biseriate \\
\hline
\end{tabular}

CYA colony diameter, color; $M E A$ colony diameter, texture their specificity. Using (ITS4-ITS5) primers, PCR generated amplicons around $600 \mathrm{bp}$ (data not shown). BLAST analysis of the calmodulin, the beta-tubulin and ITS sequences showed that there was $100 \%$ of sequence similarity of isolate C7A29 with Penicillium solitum CBS 424.89, isolate S7 with Penicillium chrysogenum CBS 109613, isolate C4A1 with Penicillium steckii CBS 139.45, isolate C6A1 with Penicillium sumatraense CBS 281.36, isolate C5A10 with Penicillium italicum CBS 339.48 and C5B1 with Penicillium citrinum CBS 139.45, isolate C7A16 with Aspergillus europaeus CCF 3365, isolate C7A13 with Aspergillus flavus NRRL3357, isolate C6B6 with Aspergillus niger CBS 513.88, isolate C5B26 with Aspergillus pulverulentus CBS 558.65 (Figs. 3, 4).

Phylogenetic analysis based on the maximum-likelihood and maximum-parsimony methods of calmodulin and betatubulin sequences revealed trees with similar topology as trees obtained in neighbor-joining analyses (Supplementary material Figure S1 and Figure S2). Isolate S7 was closely related with $P$. chrysogenum. However, the sequence from isolate S7 differed from the sequence of $P$. chrysogenum CBS: 109613 at two nucleotide positions. Moreover, isolate C6A1 and reference strain of $P$. sumatraense CBS 281.36 were clustered together in a group, although the sequence of C6A1 isolate differed from the sequence of $P$. sumatraense CBS 281.36 at two nucleotide position.

Species including Penicillium expansum (represented by three strains C4A4, C2B12 and C7A1), Penicillium allii (represented by two strains C7B20 and C1A25), Penicillium viridicatum (represented by two strains D2 and S8) and Penicillium polonicum (represented by two strains $\mathrm{C} 2 \mathrm{~A} 8$ and C7A25) were phylogenetically distinct from other species and orthologs to their reference strains (CBS 325.48, AS3.6669, SZMC 23186 and CBS 222.28, respectively) (Fig. 3). On the basis of DNA polymorphism analysis of calmodulin sequences, the latter species ( $P$. expansum, $P$. allii, Penicillium viridicatum and $P$. polonicum) formed four different haplotypes when submitted to DnaSP software (Supplementary material Table S1). Haplotype 1 was the most frequent haplotype and consisted exclusively of 4
Fig. 3 Neighbor-joining tree based on calmodulin sequences showing the phylogenetic relationship between Penicillium strains. Bootstrap values (expressed as percentages of 1000 replications) $>70 \%$ are given at the nodes

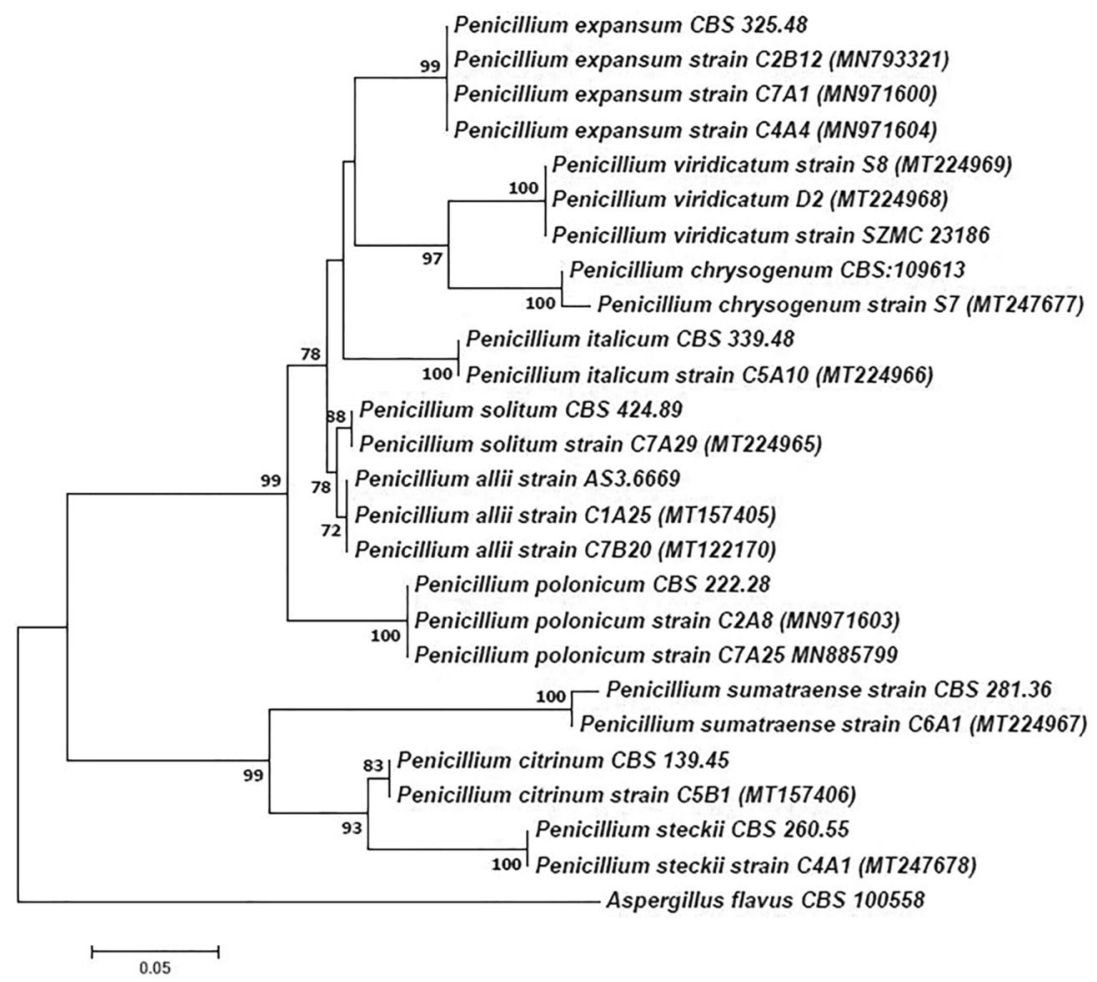


Fig. 4 Neighbor-joining tree based on beta-tubulin sequences showing the phylogenetic relationship between Aspergillus strains. Bootstrap values (expressed as percentages of 1000 replications $)>70 \%$ are given at the nodes

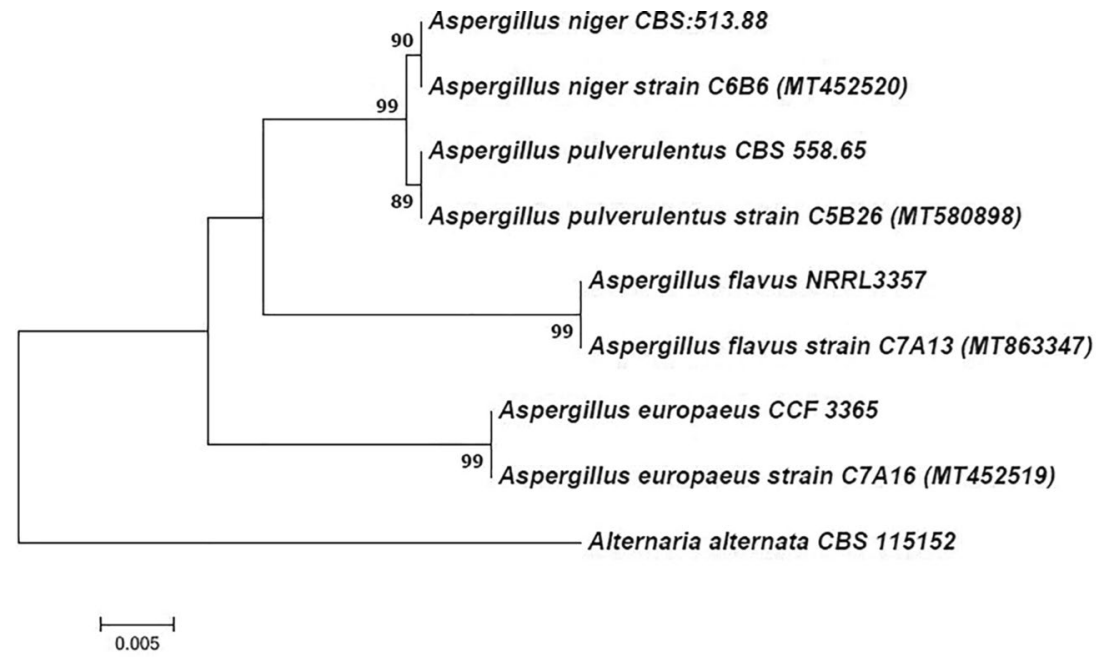

sequences of $P$. expansum (C4A4, C2B12, C7A25 and $P$. expansum type strain CBS 325.48). Haplotype 5, Haplotype 6 and Haplotype 10 corresponded to a set of 3 sequences of $P$. polonicum (C2A8, C7A25 and $P$. polonicum type strain CBS 222.28), $P$. allii (C7B20, C1 A25 and $P$. allii type strain AS3.6669) and $P$. viridicatum (D2, S8 and $P$. viridicatum type strain SZMC 23186), respectively (Supplementary material Table S2). The genetic relationship of these haplotypes was graphically displayed by the program Network version 4.5.0.0 (Supplementary material Figure S3).
Based on sequence analysis of the ITS, SPS1 and SPS2 were identified as Alternaria alternata species complexes (MT126617 and MT126618). Phylogenetic analysis was not conducted for Alternaria isolates because only two strains were amplified by ITS4 and ITS5. The calmodulin, beta-tubulin and ITS sequences were deposited in the GenBank database and their accession numbers are listed in Table 5.
Table 5 Sequence identification results for phenotypic groups analyzed in this study

\begin{tabular}{|c|c|c|c|c|}
\hline Groups & Sequence identification & Code isolate & Accession number & Frequency $(\%)$ \\
\hline \multirow[t]{2}{*}{$(1-3)$} & \multirow[t]{2}{*}{ Penicillium allii } & C7B20 & MT122170 & \multirow[t]{2}{*}{12.8} \\
\hline & & $\mathrm{C} 1 \mathrm{~A} 25$ & MT157405 & \\
\hline 2 & Penicillium citrinum & C5B1 & MT157406 & 1 \\
\hline \multirow[t]{3}{*}{$(4-7-15)$} & \multirow[t]{3}{*}{ Penicillium expansum } & $\mathrm{C} 4 \mathrm{~A} 4$ & MN971604 & \multirow[t]{3}{*}{42} \\
\hline & & $\mathrm{C} 2 \mathrm{~B} 12$ & MN79332 & \\
\hline & & C7A1 & MN971600 & \\
\hline 5 & Penicillium italicum & C5A 10 & MT224966 & 1.7 \\
\hline 6 & Penicillium sumatraense & C6A1 & MT224967 & 3.5 \\
\hline \multirow[t]{2}{*}{$(8-14)$} & \multirow[t]{2}{*}{ Penicillium viridicatum } & D2 & MT224968 & \multirow[t]{2}{*}{7.6} \\
\hline & & $\mathrm{S} 8$ & MT224969 & \\
\hline \multirow[t]{2}{*}{$(9-10)$} & \multirow[t]{2}{*}{ Penicillium polonicum } & $\mathrm{C} 2 \mathrm{~A} 8$ & MN971603 & \multirow[t]{2}{*}{16.7} \\
\hline & & C7A25 & MN885799 & \\
\hline 11 & Penicillium chrysogenum & S7 & MT247677 & 8.7 \\
\hline 12 & Penicillium solitum & C7A29 & MT224965 & 4.9 \\
\hline 13 & Penicillium steckii & C4A1 & MT247678 & 1 \\
\hline $1 \mathrm{~A}$ & Aspergillus europaeus & C7A16 & MT452519 & 11.1 \\
\hline $2 \mathrm{~B}$ & Aspergillus flavus & C7A13 & MT863347 & 20.4 \\
\hline $1 \mathrm{C}$ & Aspergillus niger & C6B6 & MT452520 & 53.7 \\
\hline $3 \mathrm{D}$ & Aspergillus pulverulentus & C5B26 & MT580898 & 14.8 \\
\hline \multirow[t]{2}{*}{$(1 a-2 b)$} & \multirow[t]{2}{*}{ Alternaria alternata } & SPS1 & MT126617 & \multirow[t]{2}{*}{5.6} \\
\hline & & SPS2 & MT126618 & \\
\hline
\end{tabular}




\section{Biodiversity of aerospores in apple warehouses}

The biodiversity of fungal species collected from the air of apple warehouses is listed in Table 5. Fifteen fungal species attributed to three genera were isolated. Penicillium, Aspergillus and Alternaria were the most common genera collected with different frequencies (Table 2). In which Penicillium was represented by ten species, followed by Aspergillus (four species), and one Alternaria species.

In this survey, Penicillium was by far the most common genus detected with a frequency of $76.8 \%$. P. expansum was the most abundant specie with $42 \%$ followed by P. polonicum (16.7\%), P. allii (12.8\%), P. chrysogenum (8.7\%), P. viridicatum (7.6\%), P. solitum $(4.9 \%)$, P. sumatraense $(3.5 \%)$ and P. italicum (1.7\%). P. citrinum and $P$. steckii occurred less frequently than the other species (1\%).

Aspergillus was the second most common identified fungal genera with a frequency of (14.4\%). Aspergillus niger was the most identified species with $53.7 \%$ followed by A. flavus (20.4\%), A. pulverulentus (14.8\%) and A. europaeus (11.1\%).

Alternaria, represented by Alternaria alternata, ranked third in abundance in indoor atmosphere of apple warehouses with (5.6\%).

\section{In vivo experiments}

\section{Undescribed fungal pathogen to apple fruit}

Ten species were found to be pathogenic at room temperature and under storage conditions. Among them, four undescribed fungal pathogen to apple fruit were observed and were able to cause decay in healthy apple fruit: A. europaeus, $A$. pulverulentus, $P$. allii and $P$. sumatraense. Lesions provoked by the later species varied in appearance and presented a light- to dark-brown color and wet to dry texture (Fig. 5).

Decayed area caused by $P$. allii and $P$. sumatraense began as water-soaked lesions and enlarged gradually in diameter and developed into brown and soft lesions. The pathogens invaded apples tissue slowly in the early stage and blue-green spores were formed on lesion surface in the late stage, starting at the infection sites.

Aspergillus europaeus and A. pulverulentus provoked brown and medium-soft lesions on infected apples. As the decayed area ages, they turned to dark brown slowly. Infected apples have an earthy odor and no apparent sporulation was observed along experiments in the inoculation spots.

The inner decayed tissue of inoculated apples appeared yellowish brown. Cross section of mold lesion on apples showed a sharp margin between decayed and healthy tissue.
Fig. 5 Golden delicious apples inoculated with A $P$. allii; $\mathbf{B}$ A. pulverulentus; C $P$. sumatraense and $\mathbf{D}$ A. europaeus. Line 1 showing symptom of mold of the four corresponding pathogens on apple, Line 2 showing cross-section of mold lesion on apple for each pathogen
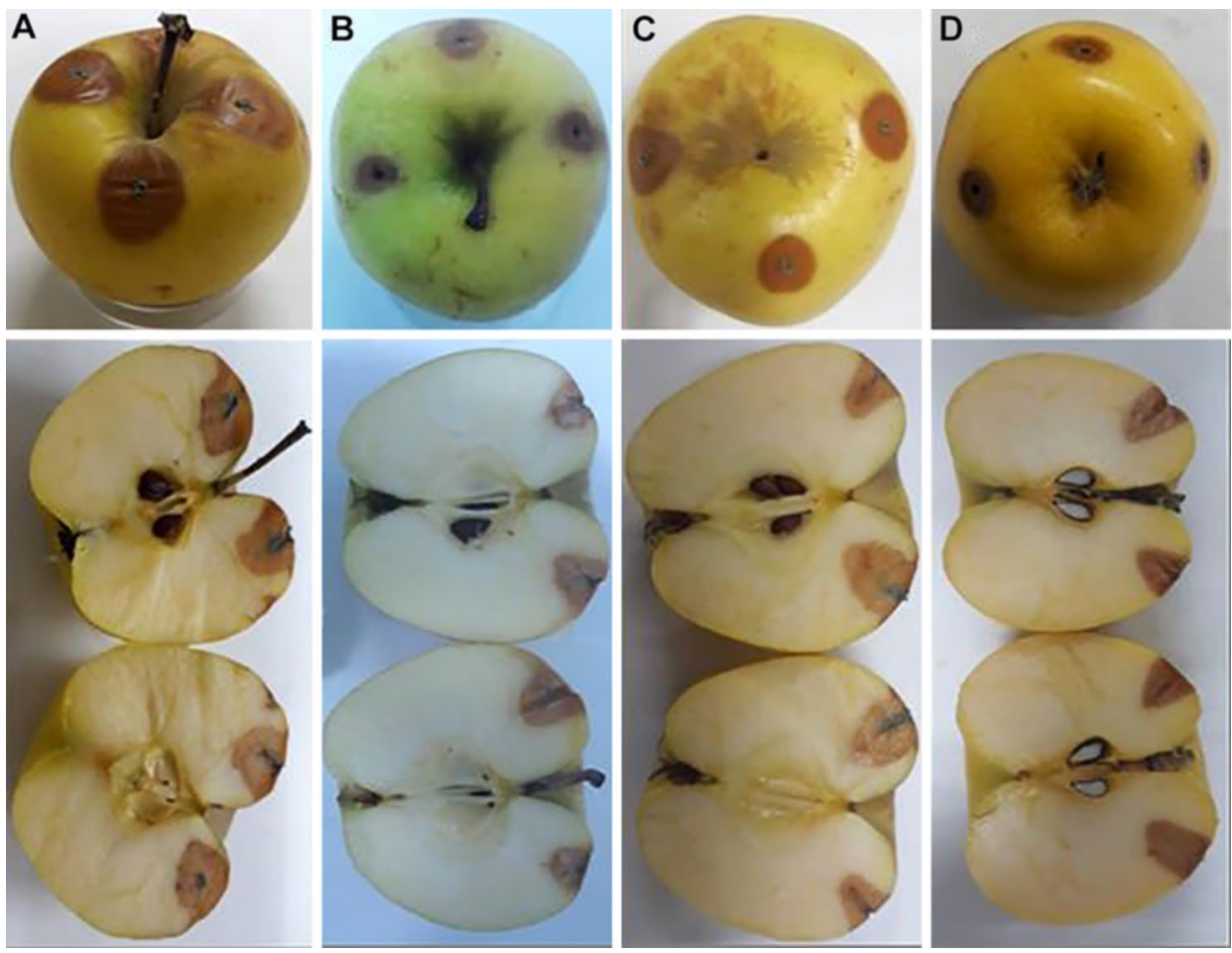
Aspergillus europaeus presented a V-shaped lesions expanding towards the core of the apple.

\section{Pathogenicity of Penicillium, Aspergillus and Alternaria isolates on apples}

In ambient conditions, all three repeats produced similar pathogenicity results. The most devastating species were $P$. expansum (C4A4) and $P$. polonicum (C2A8), generating a decay area of $37 \mathrm{~mm}$ after 7 days post-inoculation, followed by $P$. allii (C7B20) and A. flavus (C5B26) with $16 \mathrm{~mm}$. A. alternata (SP1) and P. solitum (C7A29) had a moderate pathogenicity and presented diameters of $12 \mathrm{~mm}$. Slightly brown lesions of 8 and $7 \mathrm{~mm}$ were produced by $A$. pulverulentus (C5B26) and by $P$. viridicatum (D2), respectively. Penicillium italicum (C5A10) and A. niger (C6B6) were weak pathogens and they generated the smallest decay area among all tested species (4 $\mathrm{mm})$.

Differences in terms of days to significant infection and diameters of lesions were observed among species, during cold-storage trials. Decay began to develop 5 days after inoculation for some isolates. None of the inoculated apples presented sporulation or mycelia growth on injected wounds excluding $P$. expansum, which started to develop white mycelium on day 37. Pathogenicity varied within the investigated strains and five levels were described according to days where isolates presented a significant infection. $P$. expansum, $P$. polonicum, $P$. solitum, $P$. italicum and $A$. flavus showed the first significant lesions on the fifth and the seventh day, respectively, and presented a severe pathogenicity. $P$. viridicatum and $P$. pulverulentus started to provoke lesions that were classified as moderately severe on the 9 th and 11th day, respectively. After 13 and 15 days post-inoculation, pathogenicity was described as moderate for A. europaeus, P. sumatraense and P. chrysogenum. Since the 17 th day, pathogenicity was considered mild for the four following species: A. niger, Alternaria alternata and $P$. allii (Table 6). $P$. citrinum and $P$. steckii were not pathogens to apples and did not present any lesions throughout the test period. According to the Duncan test, values of mean lesions diameters of tested species were significantly different $(p<0.001)$ and presented 11 different groups of fungi over the storage period (Table 6). Penicillium expansum generated the highest mean lesion size $(18.31 \mathrm{~mm})$ followed by $P$. solitum $(9.42 \mathrm{~mm})$. The lowest decay area was recorded in A. niger and P. chrysogenum (2.77 and $2.82 \mathrm{~mm}$, respectively). The experiment was stopped on the 43rd day due to total decay of fruit by $P$. expansum. Among tested isolates, $P$. expansum was the only species able to provoke large lesions reaching $35 \mathrm{~mm}$ on apples. Penicillium solitum was able to generate lesions; however, they were smaller than $P$. expansum (15.6 mm) followed by $P$. sumatraense $(11 \mathrm{~mm})$. All three repeats produced similar pathogenicity results during cold trials.

Table 6 Pathogenicity trials at room temperature storage conditions

\begin{tabular}{llllll}
\hline Species & $\begin{array}{l}\text { Days to signifi- } \\
\text { cant infection }\end{array}$ & Pathogenicity & $\begin{array}{l}\text { Mean lesion size at } \\
\text { day } 43(\mathrm{~mm})\end{array}$ & $\begin{array}{l}\text { Mean lesion size during } \\
\text { incubation at } 4{ }^{\circ} \mathrm{C}(\mathrm{mm})\end{array}$ & $\begin{array}{l}\text { Mean lesion size during } \\
\text { incubation at } 25{ }^{\circ} \mathrm{C} \\
(\mathrm{mm})\end{array}$ \\
\hline Penicillium citrinum & - & - & 0 & $0 \mathrm{a}$ & $0 \mathrm{a}$ \\
Penicillium steckii & - & - & 0 & $0 \mathrm{a}$ & $0 \mathrm{a}$ \\
Aspergillus niger & 17 & + & 6.33 & $2.77 \mathrm{~b}$ & $4 \mathrm{~b}$ \\
Penicillium chrysogenum & 15 & ++ & 5.5 & $2.82 \mathrm{~b}$ & $0 \mathrm{a}$ \\
Penicillium viridicatum & 9 & +++ & 4.67 & $3.28 \mathrm{~cd}$ & $7 \mathrm{c}$ \\
Alternaria alternata & 17 & + & 8.83 & $3.33 \mathrm{~cd}$ & $12 \mathrm{~d}$ \\
Penicillium allii & 17 & + & 6.3 & $3.46 \mathrm{~d}$ & $8 \mathrm{c}$ \\
Aspergillus pulverulentus & 11 & +++ & 7.17 & $3.78 \mathrm{e}$ & $0 \mathrm{a}$ \\
Aspergillus europaeus & 13 & ++ & 9.17 & $4.14 \mathrm{f}$ & $0 \mathrm{a}$ \\
Penicillium sumatraense & 13 & ++ & 11.00 & $5.14 \mathrm{~g}$ & $4 \mathrm{~b}$ \\
Penicillium italicum & 7 & ++++ & 7.33 & $5.44 \mathrm{~h}$ & $37 \mathrm{f}$ \\
Penicillium polonicum & 5 & ++++ & 9.00 & $5.87 \mathrm{i}$ & $16 \mathrm{e}$ \\
Aspergillus flavus & 7 & ++++ & 11.00 & $6.83 \mathrm{j}$ & $12 \mathrm{~d}$ \\
Penicillium solitum & 5 & ++++ & 15.6 & $9.42 \mathrm{k}$ & $37 \mathrm{f}$ \\
Penicillium expansum & 5 & ++++ & 35.33 & $18.31 \mathrm{e}$ & \\
\hline
\end{tabular}

*Values with different letter are significantly different

- No lesion observed along test period

Scale for pathogenicity: severe $(++++)$, moderately severe $(+++)$, moderate $(++)$, mild $(+),(-)$ none pathogen 


\section{Taxonomic description}

Taxonomic description, photos of colonies, and fungal structures of $P$. allii, $P$. sumatraense, A. pulverulentus and A. europaeus which are undescribed pathogen to apple fruit and novel to Tunisia are given below and presented in Figs. 6, 7,8 and 9 .

\section{Aspergillus europaeus Hubka, A. Nováková, Samson, Houbraken, Frisvad\& M. Kolař́ík (Fig. 6)}

Pl. Syst. Evol.:645 (2016)

Isolate that was examined was C7A16.

Colonies on MEA at $25^{\circ} \mathrm{C}$, after 7 days: $28 \mathrm{~mm}$, floccose, with raised colony center, colony surface delicately granular, mycelium yellowish grey, sporulation on almost entire surface, reverse brilliant yellow with greyish yellow tint in the colony center. Colonies on CYA at $25^{\circ} \mathrm{C}$, after 7 days: $38 \mathrm{~mm}$, floccose, yellowish white, sporulation yellow, poorly sporulate after 7 days, no exudate, no soluble pigment and reverse yellowish white colony.

Stipes are colorless, smooth, occasionally longer; vesicle biseriate; metulae broadening toward the top, $15 \mu \mathrm{m}$ long, phialides ampulliform, $9.1 \times 5 \mu \mathrm{m}$; conidia colorless, globose, coarsely roughened, $4.2 \mu \mathrm{m}$.

Notes: Colony characteristics and micromorphology of MT452519 agreed well with the description of A. europaeus (Hubka et al. 2016). Aspergillus europaeus bears some resemblance to $A$. wentii and $A$. dimorphicus. But the later species have globose or subglobose vesicles in contrast to pyriform vesicles of A. europaeus.

\section{Aspergillus pulverulentus (McAlpine) Wehmer (Fig. 7)}

Centralbl Bacteriol 2. Abth.18: 394 (1907).

$\equiv$ Sterigmatocystis pulverulenta McAlpine, AgricGaz New South Wales 7: 302 (1897).

Isolate that was examined was C5B26.

This strain develops quickly on CYA, produces colonies $35-40 \mathrm{~mm}$ in diameter after 7 days at $25^{\circ} \mathrm{C}$. Texture is velvety, surface black, reverse white-cream. Basal mycelium is white, exudates are small and colorless. Conidial heads are blackish grey, characteristically radiate. Colonies on MEA developed rapidly and reached $50 \mathrm{~mm}$ in diameter at $25^{\circ} \mathrm{C}$ in 7 days. Texture is velvety, surface brown and black, reverse color white; colorless exudates.
Fig. 6 Macromorphology and micromorphology of Aspergillus europaeus after 7 days of incubation at CYA, A obverse, $\mathbf{B}$ reverse, $\mathbf{C}$ Conidiophores, $\mathbf{D}$ Conidia. Scale bar $=10 \mu \mathrm{m}$
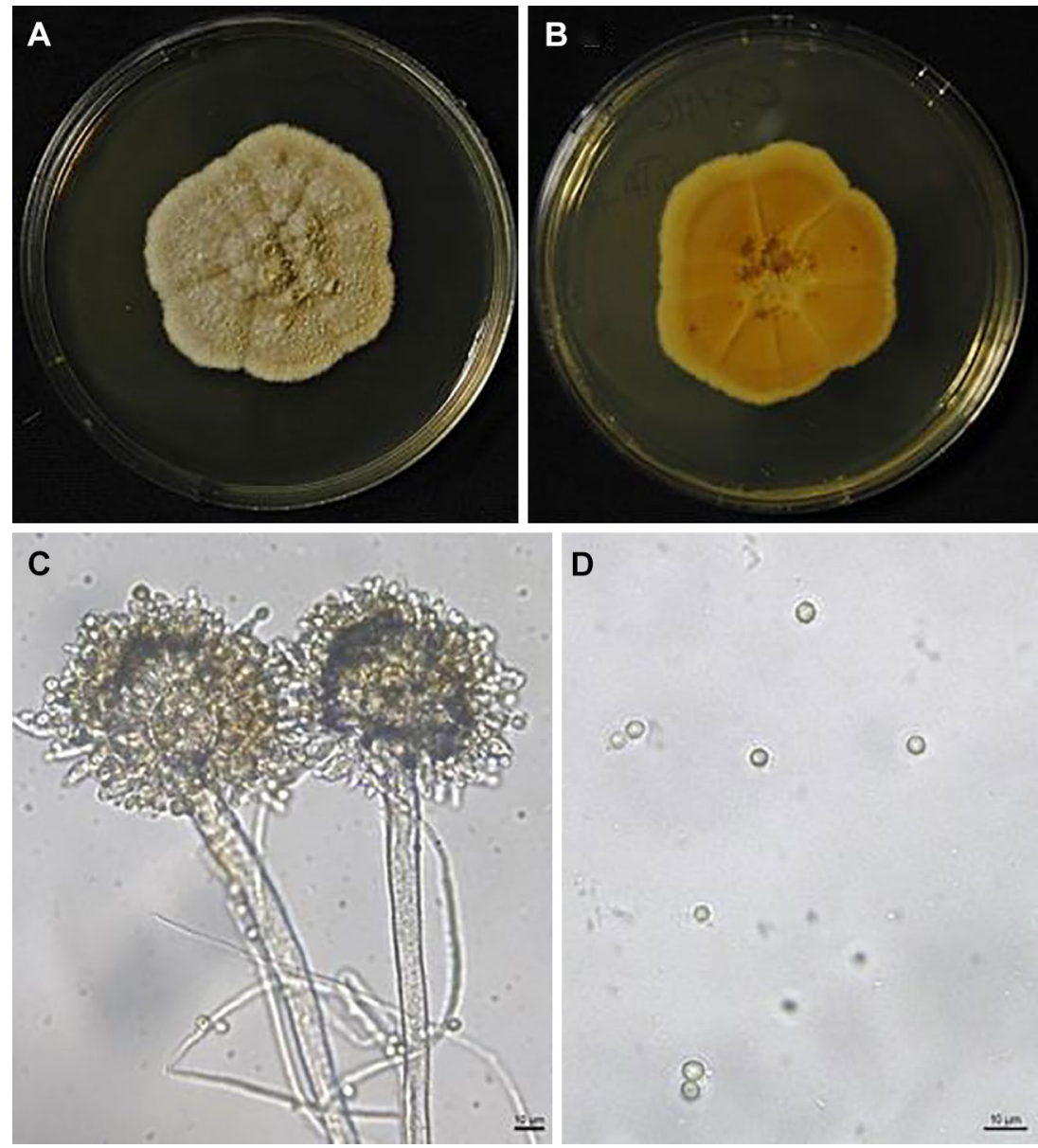
Fig. 7 Macromorphology and micromorphology of Aspergillus pulverulentus after 7 days of incubation at CYA, A obverse, B reverse, C Conidiophores, D Conidia. Scale bar $=10 \mu \mathrm{m}$
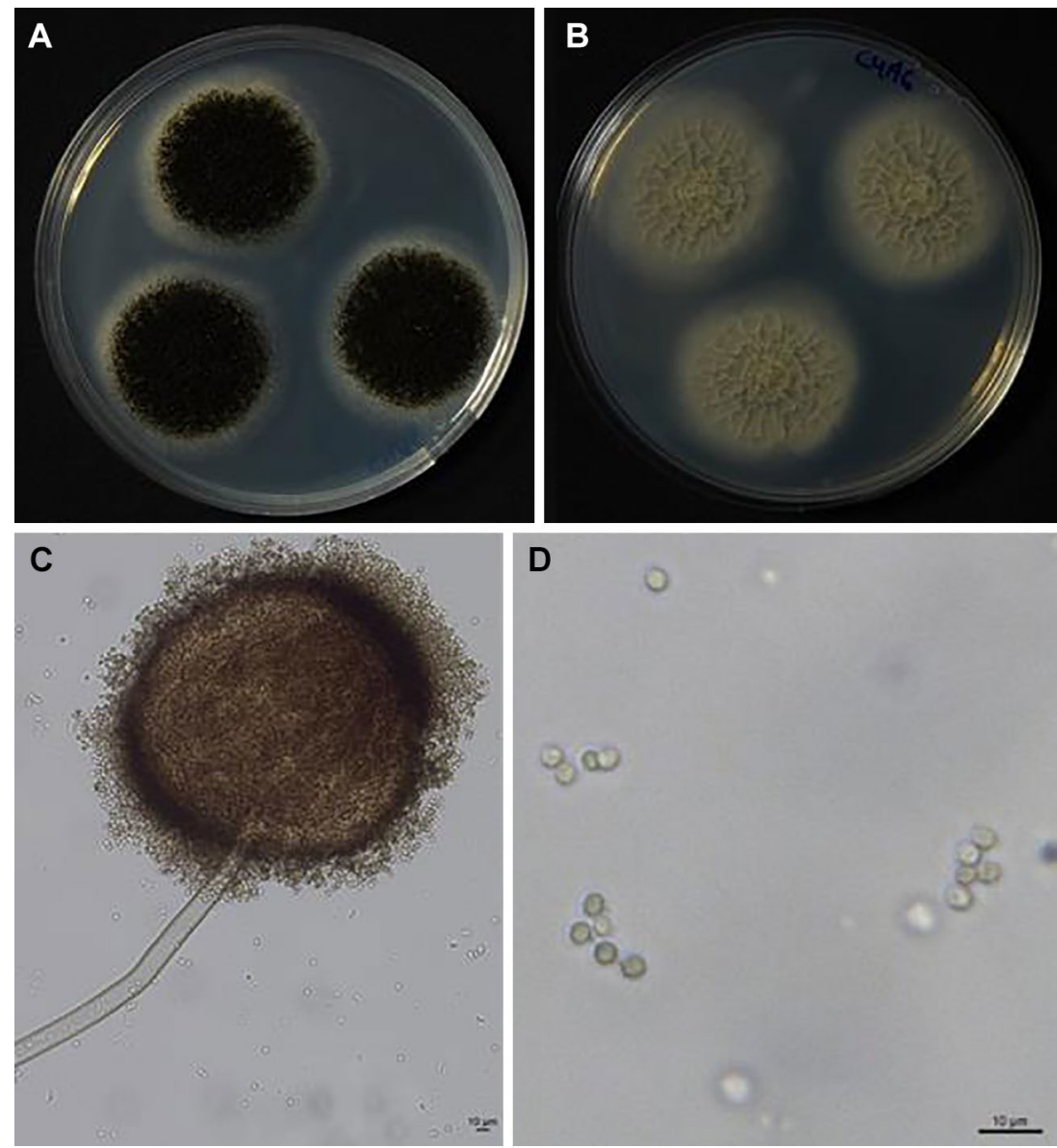

Stipes are smooth, colorless, upper parts are light brown, $15-20 \mu \mathrm{m}$ in width, 1000-3000 $\mu \mathrm{m}$ sometimes $5000 \mu \mathrm{m}$ in length. Vesicles are globose, $60-75 \mu \mathrm{m}$ in diameter. Phialide

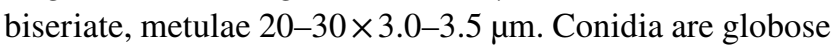
and 4.5-5.0 $\mu \mathrm{m}$ in diameter.

Notes: The strain MT580898 agreed with description of A. pulverulentus given by Thom (1926). Aspergillus pulverulentus is similar to $A$. niger in colony morphology and coloration. However, A. pulverulentus has globose to subglobose conidia, smooth to verruculose.

\section{Penicillium allii Vincent and Pitt (Fig. 8)}

Mycologia 81: 300, 1989.

$=$ Penicillium hirsutum var. allii (Vincent \& Pitt) Frisvad, Mycologia 81: 856, 1989.

Isolate that was examined was C7B20.

Penicillium allii produces colonies $38 \mathrm{~mm}$ in diameter on CYA after 1 week of incubation at $25^{\circ} \mathrm{C}$. Colony texture is Granular to weakly fasciculate and only sulcate in center of colony. Conidium is Dull green. Exudate droplets are present, small and clear. Ehrlich reaction is Pink. On MEA, colonies are $36 \mathrm{~mm}$ in diameter with grey-green conidium.
Conidiophores are Ter-verticillate, conidia $3.7 \mu \mathrm{m}$ in diameter, smooth-walled and globose; phialides $9.7 \times 3 \mu \mathrm{m}$; Metulae: $11.8 \times 2.2-3.8 \mu \mathrm{m}$; stipes are short, rough-walled, $75-400 \times 3.5-5 \mu \mathrm{m}$.

Notes: The strain C7B20 reported under the accession number MT122170 agreed with the description of $P$. allii (Vincent and Pitt 1989; Frisvad and Samson 2004). P. allii Vincent \& Pitt is a synonymous denomination of "Penicillium hirsutum Dierckx" and "Penicillium corymbiferum Westling" as used in earlier publications (Cavagnaro et al. 2005; Dugan et al. 2007, 2011; Valdez et al. 2009). This fungus differs from $P$. hirsutum by fewer and more lightly colored exudates droplets and from Penicillium crustosum by not becoming crustose on MEA.

\section{Penicillium sumatraense Szilvinyi (Fig. 9)}

Archiv. Hydrobiol. 14, Suppl. 6: 535. 1936.

Isolate that was examined was C6A1.

Colonies on CYA 33-42 mm in diameter after 7 days, velvety, conidia dull-green or dark-green, exudate absent or present as small or large (pale)-yellow droplets, occasionally clear or light brown, soluble pigments in most strains 
Fig. 8 Macromorphology and micromorphology of Penicillium allii after 7 days of incubation at A CYA and B MEA, C Conidiophores, D Conidia. Scale bar $=10 \mu \mathrm{m}$
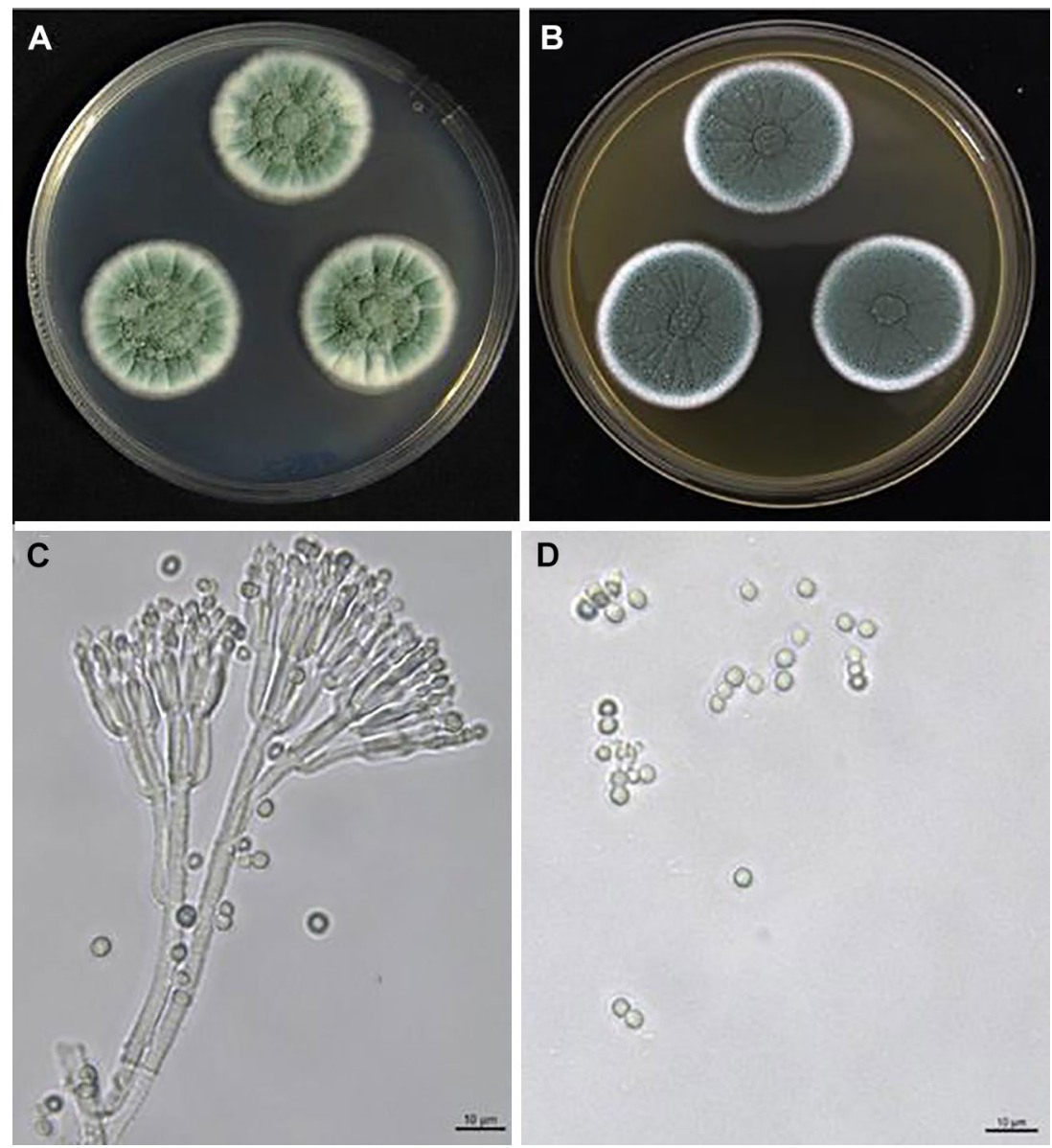

absent, in some isolates weakly produced and light-brown colored, margin entire.

Colonies on MEA 27-36 mm in diameter after 7 days, conidia blue-green, light green or grayish-green, floccose colony texture in fresh isolate. Ehrlich reaction is negative.

Conidiophores predominantly biverticillate, occasionally with an additional branch, stipes smooth or finely rough walls 2.0-3.0 $\mu \mathrm{m}$ wide. Metulae vesiculate (10-) 12-16 ×2.0-3.0 $\mu \mathrm{m}$. Phialides ampulliform, $8.0-10 \times 2-3.5 \mu \mathrm{m}$. Conidia subglobose or broadly ellipsoidal, finely roughened, occasionally smooth, $2.0-2.5 \mu \mathrm{m}$ diam.

Notes: The examined isolate MT224967 agreed well with the description of $P$. sumatraense (Houbraken et al. 2011). $P$. sumatraense was formally considered a synonym of Penicillium corylophilum (Pitt 1980), but Peterson (2000) and Houbraken and Samson (2011) showed that these two species are phylogenetically unrelated. Penicillium meleagrinum var. viridiflavum was described without a Latin diagnosis, making the description invalid. Therefore, Pitt et al. (2000) synonymized this species with Penicillium janthinellum; however, Serra et al. (2008) showed that P. meleagrinum var. viridiflavum is genetically close to the type strain of $P$. sumatraense. Therefore, they were maintained as one species.

\section{Discussion}

To our knowledge, this is the first aeromycological survey that provides an overview of fungi profile in the atmosphere of apple warehouses in Tunisia and a description of four previously unrecorded fungal pathogens of apple.

A good deal of the literature on airborne fungal spores of work places and industrial environments has been published (Simşekli et al. 1999; Sawane and Saoji 2005; Kakde and Kakde 2012; Barontini et al. 2014; Nova et al. 2015; Kozdrój et al. 2019). However, there are only a few papers which deal with airspora collected from cold-storage rooms and which have the potential to affect the quality of stored apple (Giraud and Fauré 2000; Amiri and Bompeix 2005).

Quantitative analyses of fungal spores revealed that both warehouses had more spore concentration in April than the other 2 months (1016.24 and 177.33 CFU/m ${ }^{3}$ in $\mathrm{S} 1$ and S2, respectively). The occurrence of fungal spores in cold chambers found in this study since the first month of sampling could be related to different factors such poor hygiene conditions. It has been suggested that lack of sophisticated storage rooms, poor handling practices by workers and poor sanitary conditions (Sharma et al. 2009; Kibret and Abera 2012) may highly contribute to spore dispersal, thus causing fruit decay. 
Fig. 9 Macromorphology and micromorphology of Penicillium sumatraense after 7 days of incubation at A CYA and B MEA, C Conidiophores, D Conidia. Scale bar $=10 \mu \mathrm{m}$
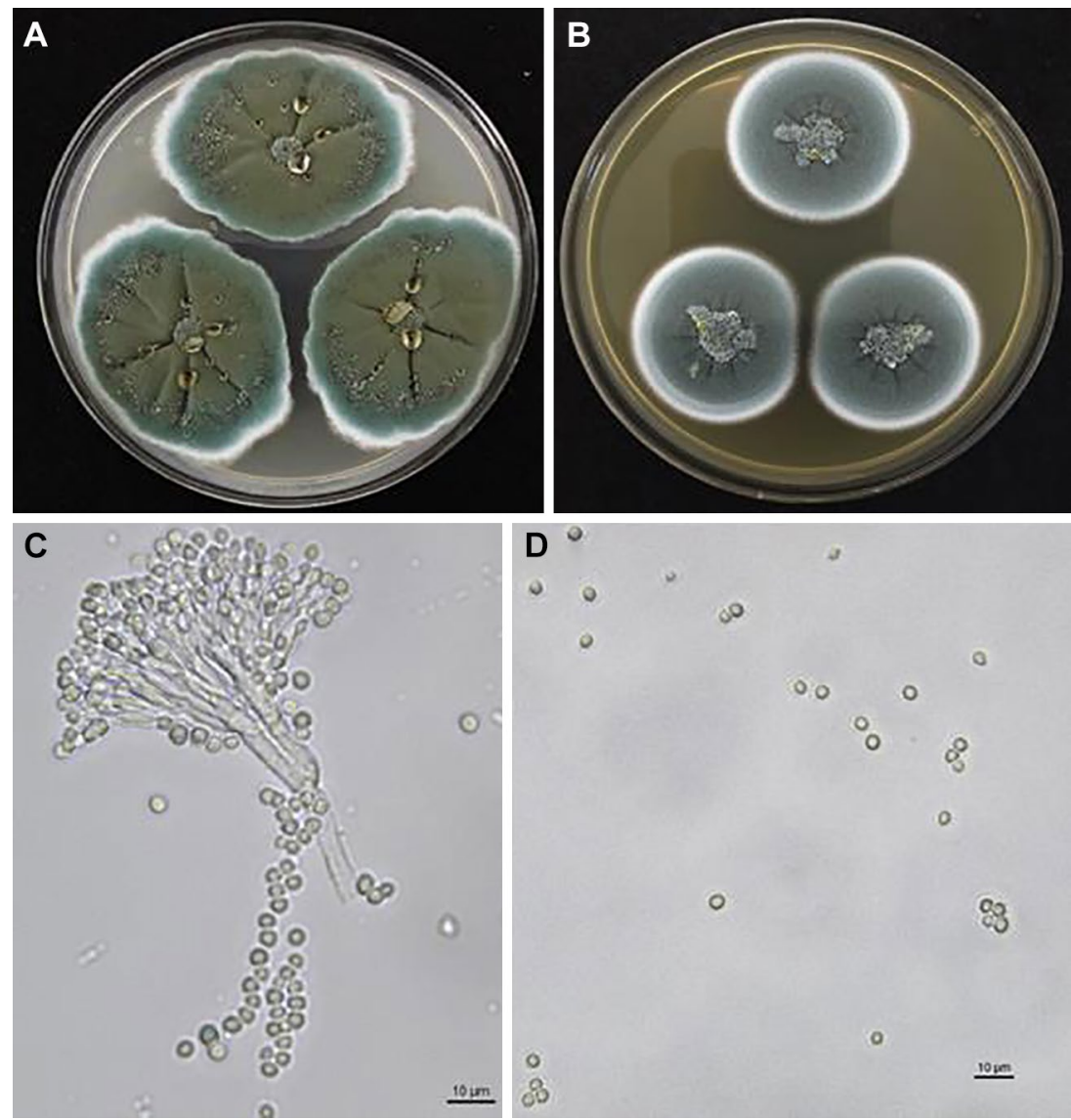

$\infty$

o

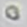

00 $\circ$ 。

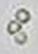

0

$\circ$

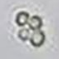

○

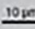

In addition, it has been reported that high spore counts in the air can be attributed to spore discharge mechanisms of the fungi, availability of substrates, temperature and humidity (Money 2015). Sufficient light and oxygen may also favor fungal growth in indoor environments (Khan and Karuppayil 2012). In addition, moving and handling fruit crates have been suggested to be factors responsible for the increase of airborne fungal spore dispersal in refrigerated rooms (Lehtonen and Reponen 1993; Grisoli et al. 2009). Moreover, unclean fruit crates, rotten fruit and discarded leaves and stems could act as substrates for fungal growth and enhance spore dispersal in air (Arya and Arya 2007; Vermani et al. 2014). In addition, the outdoor air is often reported as the dominant source of indoor fungi. Spores can usually enter a building through doors and ventilation systems, hence fungal growth and sporulation may occur (Shelton et al. 2002).

Three different fungal genera, Penicillium, Aspergillus, and Alternaria were the most occurring fungi. In several aerobiological studies, the airborne spores belonging to these three genera have been demonstrated as the most widespread fungi detected (Dhruv et al. 2010; Khan and Karuppayil 2012; Jean Phellipe et al. 2019). Furthermore, these fungi were found to be responsible for considerable postharvest disease in a similar storage unit of fruit (Oliveri et al. 2007; Barontini et al. 2014). Our results revealed that among the total counts of viable fungi identified, Penicillium (76.8\%) was the dominant genera followed by Aspergillus (14.4\%) and Alternaria (5.6\%). An abundance of Penicillium compared to the other fungi may be due to the amount of decay caused by this fungi found in these storage facilities. Amiri and Bompeix (2005) have confirmed that there is a correlation between the level of airborne Penicillium within the atmosphere of warehouses and the concentration of Penicillium spp. spores on apple surfaces. In such a manner, the decay occurring on apples in storage enhances the release of spores, thus increasing the level of airborne Penicillium. Among obtained isolates, we have determined 21 groups with distinct phenotypes. Penicillium and Aspergillus isolates were phenotypically diverse compared to Alternaria isolates. They were grouped into 15 and 5 morphologically different groups, respectively. Relying on sequencing of markers calmodulin and beta-tubulin allowed for accurate fungal identification of ten Penicillium species and four Aspergillus species. Using ITS4 and ITS5 primers, two Alternaria isolates were identified as A. alternata.

In this study, a rich diversity of airborne Penicillium spp. existed in the atmosphere of apple warehouses. These results were similar to that reported by Amiri and Bompeix (2005) in a survey conducted in cold rooms in France. However, we reported the presence of $P$. polonicum, $P$. allii, $P$. 
viridicatum, $P$. sumatraense, $P$. italicum, $P$. citrinum and $P$. steckii, which were not identified in the later study. Similar Penicillium species were also reported in the pear fruit chain (Scholtz and Korsten 2016) except for P. allii, P. viridicatum, $P$. sumatraense and $P$. steckii. No other similar study could be found for comparative purposes.

Penicillium expansum, $P$. polonicum, $P$. allii and $P$. chrysogenum represented approximately $80 \%$ of the total Penicillium species isolated. According to literature, these species were commonly associated with apple during the postharvest stage except for $P$. allii. Other Penicillium species identified in this study accounted for $20 \%$ of the total Penicillium population. Penicillium expansum scored the highest frequency and was the most dominant specie detected in the atmosphere. This is in agreement with that study that investigated airborne Penicillium from the atmosphere of cold rooms in France (Amiri et al. 2005). Several studies reported that $P$. expansum is considered among the most economically important postharvest spoilage fungal species that causes decay in cold-stored pome fruits and found mainly in warehouses (Ye et al. 2012; Vico et al. 2014a,b; Víctor et al. 2014; Grantina-Ievina 2015; Gong et al. 2019). Penicillium polonicum was the second most dominant Penicillium specie found in this study. This specie was isolated by Scholtz and Korsten (2016) from the pear export chain. In addition, $P$. polonicum is common to cause decay in postharvest environment on stored onions (Duduk et al. 2014), stored yam (Kim et al. 2008) and stored cactus pear (Faedda et al. 2015). In this study, P. polonicum recorded a severe pathogenicity similar to $P$. expansum. This can be explained by apple cultivar sensitivity towards pathogens which plays an important role in pathogen invasion (Louw and Korsten 2014). Penicillium chrysogenum was also detected from the atmosphere of sampled cold rooms. This specie was isolated from the air of different environment and it was also detected on stored apple (Alwakeel 2013).

Penicillium chrysogenum is regarded as one of the most common representatives of its genus in indoor environments because of its ability to grow at low water activities. It was reported as an important fungal pathogen known to be found in temperate regions (Filtenborg et al. 1996) and to be associated with saprophytic colonization of wounded or decaying fruit.

Penicillium viridicatum, $P$. solitum, $P$. sumatraense, $P$. italicum, $P$. citrinum and $P$. steckii have been isolated at a frequency of less than $8 \%$. Most of these species are ubiquitous in the food environment and are typical indoor environmental organisms. They were reported in several aeromycological studies (Johnston 2008; Altunatmaz et al. 2012; Scholtz and Korsten 2016).

Aspergillus was the second most common identified fungal genera from the atmosphere of cold rooms. Aspergillus niger and A. flavus represented approximately $75 \%$ of the total Aspergillus species isolated. Conidia of Aspergillus spp are commonly recovered from both indoors environments and outside (Gautam et al. 2011). It has been suggested that Aspergillus conidia released in the air may remain airborne for prolonged periods. Therefore, spores founded in the atmosphere could contaminate anything in contact with air (Richardson 1998). Aspergillus niger is most commonly found on decaying vegetation or soil and plants (Schuster et al. 2002).It causes rot in many fruits including apples (Liu et al. 2017; Zhang et al. 2018). Aspergillus flavus is a common constituent of airborne mycoflora. It could infect cottonseed, feed crops and apples under specific environmental conditions (Hasan 2000a,b; Bock et al. 2004). The presence of A. flavus in indoor environment should be of concern because it has been reported that $65 \%$ of airborne A. flavus produced aflatoxin (Holtmeyer and Wailin 1980), a carcinogenic toxin that cause liver cancer. Then, Aflatoxin synthesis starts simultaneously with spore emergence, and culminates with maximum spore yield.

In this study, Alternaria, represented by Alternaria alternata, ranked third in abundance in indoor atmosphere of apple warehouses. It has been reported that the indoor level of Alternaria spores in the air is influenced by the activity in the room, changes in temperature and relative humidity and the ventilation rate (Woudenberg et al. 2015). Alternaria alternata is known to cause decay on apple fruit during storage (Jurick et al. 2014) and Alternaria blotch in the orchard (Li et al. 2012).

The cold-storage trial was performed to determine pathogenicity potential of collected airborne fungi on apples during storage. Thirteen of the 15 species produced lesions on apples at cold-storage temperature.

The ability of these species to cause disease symptoms under storage conditions makes them important pathogens to consider in apple warehouses. Among them, we found four undescribed fungal pathogen to apple; A. europaeus, A. pulverulentus, $P$. allii and $P$. sumatraense. This could be explained by cross-contamination phenome.

In this study, apart from apples, other fruits were also stored in sampled cold rooms. Scholtz and Korsten (2016) reported that environmental isolates that originate from different areas (e.g., surfaces, air, and other fruit sources) may cross-infect different fruit types. The risk of cross-contamination therefore exists in areas where various fruit types from diverse origins are received and stored.

A. europaeus was described for the first by Hubka et al. (2016) by re-identifying some Aspergillus isolates collected during surveys of the soil in Romania, Spain and Czech Republic, France and Tunisia. It has been reported from corn grain in Korea (Nguyen et al. 2020). To our knowledge, this is the first report of A. europaeus pathogenic to apple.

The strain MT580898 agreed with description of $A$. pulverulentus given by Thom (1926). It has been isolated 
from soil of Wadi El Natrun, Egypt (Moubasher et al. 2015), from vineyards in Turkey (Eltem et al. 2004). In our study, it is the first record in Tunisia and pathogenic to apple.

The strain C7B20 reported under the accession number MT122170 agreed with the description of $P$. allii (Frisvad and Samson 2004; Vincent and Pitt 1989).P. allii is the main postharvest pathogen of garlic (Allen 2009). The fungus has been reported in Argentina (Valdez et al. 2006) and many other countries (Frisvad and Samson 2004). This is the first record of $P$. allii in Tunisia and virulent to apple.

The examined isolate MT224967 agreed well with the description of $P$. sumatraense (Houbraken et al. 2011). This fungus has been reported from marine environments (Malmstrøm et al. 2000), from cork (Serra et al. 2008), packaging material imported into the Netherlands, pomegranates and bromeliad leaf tissue, from grapes in Iran (Mahdian and Zafari, 2016). P. sumatraense has also been isolated from soil from Ras Rajel, in Tunisia (Houbraken et al. 2011). In our study, $P$. sumatraense was newly described as pathogenic to apple.

This finding confirms first that elucidating which microorganisms are present in indoor air is fundamentally important to assess decay incidence in storage rooms. Second, airborne fungi in apple warehouses could persist, invade and infect apples during storage at low temperature. An increase of the number of storage facilities sampled, extending the sampling period and studying pathogenicity of the isolates on a large range of apple cultivars are required. Further studies must be undertaken on mycotoxin content and effect on apple, related to the four discovered species: A. europaeus, A. pulverulentus, $P$. allii and $P$. sumatraense.

\section{Conclusion}

Quantitative and qualitative analysis of air samples showed that two investigated apple warehouses in Tunisia were loaded with large quantities of airborne fungi and were contaminated by three major fungal spore type Penicillium, Aspergillus and Alternaria. Molecular identification using calmodulin, b-tubulin and ITS in conjunction with phenotypic characterization helped to identify 15 species of fungi. Thirteen species were confirmed to be associated with fruit decay at ambient temperature and cold-storage trials. Among them, $P$. allii, A. pulverulentus, A. europaeus and $P$. sumatraense were described for the first time as pathogenic on apples. The presence of these pathogens affects the quality of indoor air and poses a potential threat to stored apple shelf life. Vigilant fruit handling, cold room sanitation and correct temperature management during storage are, therefore, essential in reducing fruit losses during storage.
Supplementary Information The online version contains supplementary material available at https://doi.org/10.1007/s00203-021-02551-9.

Acknowledgements This work was supported by funds from the VRR Project (no. 0310) and by the Ministry of Higher Education and Scientific Research of Tunisia (LR16ES05).

Author contributions Marwa SMIRI carried out the experiment and wrote the manuscript with support from Najla SADFI, Eduardo Antonio Espeso and Mustapha Rouissi and Mohamed Zouaoui. Najla SADFI supervised the Project. Amina Kheireddine helped in sampling. Eduardo Antonio Espeso contributed to molecular analysis. All the authors read and approved the manuscript.

Funding This study was funded by Ministry of Higher Education and Scientific Research of Tunisia (LR16ES05) and by funds from the Project of Valorization of Results (VRR no. 0310).

Availability of data and material All data generated or analyzed during this study are included in this published article.

\section{Declarations}

Conflict of interest The authors declare that they have no conflict of interest.

Ethical approval This article does not contain any studies with human participants or animals performed by any of the authors.

Informed consent All the authors consent to this submission.

\section{References}

Agriopoulou S, Stamatelopoulou E, Varzakas T (2020) Advances in occurrence, importance, and mycotoxin control strategies: prevention and detoxification in foods. Foods 9:137

Allen J (2009) Garlic production factsheet. Ontario Ministry of Agriculture, Food and Rural Affairs, order no. 09-011W AGDEX 258/13, 8

Altunatmaz SS, Issa G, Aydin A (2012) Detection of airborne psychrotrophic bacteria and fungi in food storage refrigerators. Braz $\mathrm{J}$ Microbiol 43:1436-1443

Alwakeel SS (2013) Molecular identification of isolated fungi from stored apples in Riyadh, Saudi Arabia. Saudi J Biol Sci 20:311-317

Amiri A, Bompeix G (2005) Diversity and population dynamics of Penicillium spp. on apples in pre- and postharvest environments: consequences for decay development. Plant Pathol 54(1):74-81

Amiri A, Cholodowski D, Bompeix G (2005) Adhesion and germination of waterborne and airborne conidia of Penicillium expansum to apple and inert surfaces. Physiol Mol Plant Pathol 67(1):40-48

Arya C, Arya A (2007) Aeromycoflora of fruit markets of Baroda, India and associated diseases of certain fruits. Aerobiologia 23:283-289

Azam M, Shahid AA, Majeed RA, Ali M, Ahmad N, Haider MS (2016) First report of Penicillium biourgeianum causing post-harvest fruit rot of apple in Pakistan. Plant Dis 100:1778

Bahri BA, Belaid Y, Mechichi G, Rouissi W (2019) Diversity of pathogenic fungi associated with apples in cold storage facilities in Tunisia. J Am Pomol Soc 73:62-75 
Barontini M, Crognale S, Scarfone A, Gallo P, Gallucci F, Petruccioli $\mathrm{M}$ et al (2014) Airborne fungi in biofuel wood chip storage sites. Int Biodeterior Biodegradation 20:17-22

Bock CH, Mackey B, Cotty PJ (2004) Population dynamics of Aspergillus flavus in the air of an intensively cultivated region of southwest Arizona. Plant Pathol 53:422-433

Cavagnaro PF, Camargo A, Piccolo RJ, Garcia Lampasona S, Burba JL, Masuelli RW (2005) Resistance to Penicillium hirsutum Dierckx in garlic accessions. Eur J Plant Pathol 112:195-199

da Rocha Neto AC, Luiz C, Maraschin M, Di Piero RM (2016) Efficacy of salicylic acid to reduce Penicillium expansum inoculum and preserve apple fruits. Int J Food Microbiol 221:54-60

Darolt JC, Rocha Neto AC, Di Piero RM (2016) Effects of the protective, curative, and eradicative applications of chitosan against Penicillium expansum in apples. Braz J Microbiol 47(4):1014-1019

Despot DJ, Klaric MS (2014) A year-round investigation of indoor airborne fungi in Croatia. Arch Ind Hyg Toxicol 65:209-218

Dhruv S, Dutta B, Singh A (2010) Exposure to indoor fungi in different working environments: a comparative study. Aerobiologia 26:327-337

Duduk N, Vasić M, Vico I (2014) First report of Penicillium polonicum causing blue mold on stored onion (Allium cepa) in Serbia. Plant Dis 98:1440

Dugan F (2006) The Identification of Fungi: An Illustrated Introduction With key, Glossary and Guide to Literature. APS Publication, St. Paul, MN

Dugan FM, Hellier BC, Lupien SL (2007) Pathogenic fungi in garlic seed cloves from the United States and China, and efficacy of fungicides against pathogens in garlic germplasm in Washington state. J Phytopathol 155:437-445

Dugan FM, Hellier BC, Lupien SL (2011) Resistance to Penicillium allii in accessions from a national plant germplasm system allium collection. Crop Prot 30:483-488

Eltem R, Apkun T, Sarig N, Zkale Tapkin E, Efendüler H (2004) Colonial and morphological characteristics of some Aspergillus Fr.:Fr. Species isolated from vineyards in Manisa and Üzmir provinces (Turkey). Turk J Bot 28:287-298

Faedda R, Pane A, Cacciola SO, Granata G, Salafia L, Sinatra F (2015) Penicillium polonicum causing a postharvest soft rot of cactus pear fruits. Acta Hortic 1067:193-197

Fernández-Cruz ML, Mansilla ML, Tadeo JL (2010) Mycotoxins in fruits and their processed products: analysis, occurrence and health implications. J Adv Res 1:113-122

Filtenborg O, Frisvald JC, Thrane U (1996) Moulds in food spoilage. Int J Food Microbiol 33:85-102

Di Francesco A, Cameldi I, Neri F, Barbanti L, Folchi A, Spadoni A, Baraldi E (2019) Effect of apple cultivars and storage periods on the virulence of Neofabraea spp. Plant Pathol 68:1525-1532

Frisvad JC, Samson RA (2004) Polyphasic taxonomy of Penicillium subgenus Penicillium. A guide to identification of food and airborne terverticillate Penicillia and their mycotoxins. Stud Mycol 49:1-174

Gara A, Abdelhafidh H, Hammemi M, Aloui M (2019) Analysis of the apple value chain at Sbiba region, Tunisia. J New Sci Agric Biotechnol 63:3972-3988

Gautam AK, Sharma S, Avasthi S, Bhadauria R (2011) Diversity, pathogenicity and toxicology of A. niger: An important spoilage fungi. Res J Microbiol 6:270-280

GIFRUITS 2018Pommes actualités. http://gifruits.com/?p=2053\& lang=fr. Accessed 2 Oct 2020

Giraud M, Fauré J (2000) Assessment of Penicillium risk on pome fruit in storage. In: Proceedings of the 5th workshop on integrated control of pome fruit diseases, Fontevraud (France), pp 24-27

Gong D, Bi Y, Li Y, Zong Y, Han Y, Prusky D (2019) Both Penicillium expansum and Trichothecim roseum infections promote the ripening of apples and release specific volatile compounds. Front Plant Sci 10:338

Grantina-Ievina L (2015) Fungi causing storage rot of apple fruit in integrated pest management system and their sensitivity to fungicides. Rural Sustain Res 34(329):1-10

Grisoli P, Rodolfi M, Villani S, Grignani E, Cottica D, Berri A, Dacarro C (2009) Assessment of airborne microorganism contamination in an industrial area characterized by an open composting facility and a wastewater treatment. J Plant Environ Res 109:135-142

Hasan H (2000a) Patulin and aflatoxin in brown rot lesion of apple fruits and their regulation. World J Microbiol Biotechnol $16: 607-612$

Hasan H (2000b) Patulin and aflatoxin in brown rot lesion of apple fruits and their regulation. World J Microbiol Biotechnol 16(7):607-612

Holtmeyer MG, Wailin JR (1980) Identification of aflatoxin producing atmospheric isolates of Aspergillus flavus. Phytopathology 70:325-327

Houbraken J, Frisvad J, Samson R (2011) Taxonomy of Penicillium section citrina. Stud Mycol 70:53-138

Houbraken J, Samson RA (2011) Phylogeny of Penicillium and the segregation of Trichocomaceae into three families. Stud Mycol 70:1-51

Hubka V, Nováková A, Samson RA, Houbraken J, Frisvad JC, Sklenář Ek, Varga J, Kolařík M (2016) Aspergillus europaeus sp. nov., a widely distributed soil-borne species related to A. wentii (section Cremei). Plant Syst Evol 302:641-650

Iqbal HM, Yousaf S, Khurshid S, Akbar QUA, Arif S, Fatima N, Rahoo AM (2019) Postharvest Physiological Disorders and organoleptic properties in relation to fungal disease incidence in citrus. $\mathrm{J}$ Innov Sci 5(1):6-11

Jean Phellipe MN, Ana MQL, Mykaella AA, Lucas AA, Eurípedes ASF (2019) Airborne fungi in indoor hospital environments. Int J Curr Microbiol App Sci 8(1):2749-2772

Johnston C (2008) Identification of Penicillium species in South African litchi export Chain. MSc thesis, University of Pretoria, Pretoria, South Africa

Jurick WM II, Kou LP, Gaskins VL, Luo YG (2014) First Report of Alternaria alternata causing postharvest decay on apple fruit during cold storage in Pennsylvania. Plant Dis 98(5):690-690

Kakde UB, Kakde HU (2012) Incidence of post-harvest disease and airborne fungal spores in a vegetable market. Acta Bot Croat 71(1):147-157

Khan AAH, Karuppayil SM (2012) Fungal pollution of indoor environments and its management. Saudi J Biol Sci 19:405-426

Kibret M, Abera B (2012) The sanitary conditions of food service establishments and food safety knowledge and practices of food handlers in Bahir Dar Town. Ethiop J Health Sci 22(1):27-35

Kim WK, Hwang YS, Yu SH (2008) Two species of penicillium associated with blue mold of yam in Korea. Mycobiology 36:217-221

Kozdrój J, Frączek K, Ropek D (2019) Assessment of bioaerosols in indoor air of glasshouses located in a botanical garden. Build Environ 166:106436

Kumar S, Stecher G, Tamura K (2016) MEGA7: Molecular evolutionary genetics analysis version 7.0 for bigger datasets. Mol Biol Evol 33:1870-1874

Lehtonen M, Reponen T (1993) Everyday activities and variation of fungal spore concentration in indoor air. Int J Biodeterior Biodegrad 31:25-39

Li Y, Aldwinckle HS, Sutton T, Tsuge T, Kang G, Cong PH, Cheng ZM (2012) Interactions of apple and the Alternaria alternata apple pathotype. Crit Rev Plant Sci 32:141-150

Liu D, Coloe S, Baird R, Pederson J (2000) Rapid mini-preparation of fungal DNA for PCR. J Clin Microbiol 38(1):471 
Liu CQ, Hu KD, Li TT, Yang Y, Yang F, Li YH, Al E (2017) Polygalacturonase gene $\mathrm{pgxB}$ in Aspergillus niger is a virulence factor in apple fruit. PLoS ONE 12:e0173277

Louw JP, Korsten L (2014) Pathogenic Penicillium spp. on apple and pear. Plant Dis 98(5):590-598

Lucas GB, Campbell C, Lucas LT (1992) Diseases caused by airborne fungi. Introduction to plant diseases. Springer, Boston, MA

Mahdian S, Zafari D (2016) First report of table grape blue mold caused by Penicillium sumatrense in Iran. Plant Dis 101

Malmstrøm J, Christophersen C, Frisvad JC (2000) Secondary metabolites characteristic of Penicillium citrinum, Penicillium steckii and related species. Phytochemistry 54:301-309

Mari M, Guidarelli M, Martini C et al (2012) First report of Colletotrichum acutatum causing bitter rot on apple in Italy. Plant Dis 96:144

Money NP (2015) Spore production, discharge and dispersal. Academic Press, London

Moubasher AH, Ismail MA, Hussein NA, Gouda HA (2015) Osmophilic/osmotolerant and halophilic/halotolerant mycobiota of soil of Wadi El-Natrun regions. J Basic Appl Mycol 6:27-42

Nabi SU, Raja WH, Kumawat KL, Mir JI, Sharma OC, Singh DB, Sheikh MA (2017) Post harvest diseases of temperate fruits and their management strategies-a review. Indian J Pure Appl Biosci $5(3): 885-898$

Nguyen TTT, Pangging M, Bangash NK, Lee HB (2020) Five new records of the family Aspergillaceae in Korea, Aspergillus europaeus, A. pragensis, A. tennesseensis, Penicillium fluviserpens, and $P$. scabrosum. Mycobiology 48:81-94

Nova WP, Andika S, Latifah Z, Darmadji P, Endang R (2015) Airborne fungi and aflatoxin-producing Aspergillus flavus group on gaplek (dried cassava) storage warehouse in Gunung Kidul, Yogyakarta, Indonesia. Asian J Microbiol Biotechnol Environ Sci 17:785-798

O'gorman CM, Fuller HT (2008) Prevalence of culturable airborne spores of selected allergenic and pathogenic fungi in outdoor air. Atmos Environ 42:4355-4368

Oliveri C, Campisano A, Catara A, Cirvilleri G (2007) Characterization and faflp genotyping of Penicillium strains from postharvest samples and packing house environments. J Plant Pathol 89(1):29-40

Peterson SW (2000) Phylogenetic analysis of Penicillium species based on ITS and LSU-rDNA nucleotide sequences. In: Samson RA,Pitt JI (eds) Integration of modern taxonomic methods for Penicillium and Aspergillus classification Plenum Press, New York, pp 163-178

Peter KA, Vico I, Gaskins V, Janisiewicz WJ, Saftner RA, Jurick Ii WM (2012) First report of Penicillium carneum causing blue mold on stored apples in Pennsylvania. Plant Dis 96:1823-1823

Pitt JI, Samson RA, Frisvad JC (2000) List of accepted species and their synonyms in the family Trichocomaceae. In: Samson RA, Pitt JI (eds) Integration of modern methods for Penicillium and Aspergillus classification. HarwoodAcademic Publishers, Amsterdam, pp 9-49

Rharmitt S, Hafidi M, Hajjaj H, Scordino F, Giosa D, Giuffre L et al (2016) Molecular characterization of patulin producing and non-producing Penicillium species in apples from Morocco. Int J Food Microbiol 217:137-140

Richardson MD (1998) Topley \& Wisons`s microbiology and microbial infections medical mycology. Arnold, London

Romanazzi G, Feliziani E (2014) Botrytis cinerea (Gray Mold). Elsevier, London

Rotem J (1994) The genus Alternaria: biology, epidemiology and pathogenicity. The American Phytopathological Society, St. Paul, p 326
Samson RA, Visagie CM, Houbraken J, Hong SB, Hubka V, Klaassen CHW et al (2014) Phylogeny, identification and nomenclature of the genus Aspergillus. Stud Mycol 78:141-173

Sawane AM, Saoji AA (2005) Airborne Penicillium in the grain shops of Nagpur (India). Grana 44:123-128

Schoch CL, Seifert KA, Huhndorf S, Robert V, Spouge JL, Levesque CA et al (2012) Nuclear ribosomal internal transcribed spacer (ITS) region as a universal DNA barcode marker for fungi. Proc Natl Acad Sci USA 109:6241-6246

Scholtz I, Korsten L (2016) Profile of Penicillium species in the pear supply chain. Plant Pathol 65:1126-1132

Schuster E, Dunn-Coleman N, Frisvad J, Van Dijck P (2002) On the safety of Aspergillus niger - a review. Appl Microbiol Biotechnol 59:426-435

Serra R, Peterson SW, CTCOR, Venâncio A (2008) Multilocus sequence identification of Penicillium species in cork bark during plank preparation for the manufacture of stoppers. Res Microbiol 159:178-186

Sharma RR, Singh D, Singh R (2009) Biological control of postharvest diseases of fruits and vegetables by microbial antagonists: a review. Biol Control 50:205-222

Shelton B, Kirkland K, Flanders W, Morris G (2002) Profiles of airborne fungi in buildings and outdoor environments in the United States. Appl Environ Microbiol 68:1743-1753

Sholberg PL, Harlton C, Haag P, Levesque CA, O'Gorman D, Seifert K (2005) Benzimidazole and diphenylamine sensitivity and identity of Penicillium spp. that cause postharvest blue mold of apples using $\beta$-tubulin gene sequences. Postharvest Biol Technol 36:41-94

Shtienberg D (2012) Effects of host physiology on the development of core rot, caused by Alternaria alternate, in red delicious apples. Phytopathology 102(8):769-778

Şimşekli Y, Gücin F, Asan A (1999) Isolation and identification of indoor airborne fungal contaminants of food production facilities and warehouses in Bursa, Turkey. Aerobiologia 15:225-231

Singh BK, Yadav KS, Verma A (2017) Impact of postharvest diseases and their management in fruit crops: an overview. J Bio Innov 6(5):749-760

Spadaro D, Dianpeng Z, Garibaldi A, Gullino ML (2010) Effect of culture media and $\mathrm{pH}$ on the biomass production and biocontrol efficacy of a Metschnikowia pulcherrima strain to be used as a biofungicide for postharvest disease control. Can J Microbiol $56: 128-137$

Spadaro D, Lorè A, Amatulli MT, Garibaldi A, Gullino ML (2011) First report of Penicillium griseofulvum causing blue mold on stored apples in Italy (Piedmont). Plant Dis 95:76

Spotts RA, Cervantes LA, Mielke EA (1999) Variability in postharvest decay among apple cultivars. Plant Dis 83:1051-1054

Sutton TB (2014) Bitter rot. The American Phytopathological Society, Paul

Thom C (1926) The genus Aspergillus

Tiwari K, Jadhav S, Kumar A (2011) Morphological and molecular study of different Penicillium species. Middle-East J Sci Res 7:203-210

Valdez JG, Makuch MA, Ordovini AF, Masuelli RW, Overy DP, Piccolo RJ (2006) First report of Penicillium allii as a field pathogen of garlic (Allium sativum). Plant Pathol 55:583

Valdez JG, Makuch MA, Ordovini AF, Frisvad JC, Overy DP, Masuelli RW, Piccolo RJ (2009) Identification, pathogenicity and distribution of Penicillium spp. isolated from garlic in two regions in Argentina. Plant Pathol 58:352-361

Vermani M, Bedi N, Hussain MS (2014) Prevalence of culturable airborne fungi in fruit markets of Delhi and Noida, India. Int Res J Environ Sci 3(7):1-6 
Vico I, Duduk N, Vasić M, Nikolić M (2014a) Identification of Penicillium expansum causing postharvest blue mold decay of apple. $\mathrm{J}$ Pesticides Phytomed 29(4):257-266

Vico I, Gaskins V, Duduk N, Vasić M, Yu JJ, Peter KA, Jurick Ii WM (2014b) First report of Penicillium crustosum causing blue mold on stored apple fruit in Serbia. Plant Dis 98:1430-1430

Víctor G, Cesar G, David B, Damaris O (2014) Complete control of Penicillium expansum on apple fruit using a combination of antagonistic yeast Candida oleophila. Chile J Agric Res 74(4):427-431

Vincent MA, Pitt JI (1989) Penicillium Allii a new species from Egyptian garlic. Mycologia 81:300-303

Visagie CM, Houbraken J, Frisvad JC, Hong SB, Klaassen CH, Perrone $\mathrm{G}$ et al (2014) Identification and nomenclature of the genus Penicillium. Stud Mycol 78:343-371

Wenneker M, Thomma BPHJ (2020) Latent postharvest pathogens of pome fruit and their management: from single measures to a systems intervention approach. Eur J Plant Pathol 156:663-681

White T, Bruns T, Lee S, Taylor J (1990) Amplification and direct sequencing of fungal ribosomal RNA Genes for phylogenetics. In: PCR - protocols and applications — a laboratory manual. Academic Press, Cambridge

Woudenberg JHC, Van Der Merwe NA, Jurjević Ž, Groenewald JZ, Crous PW (2015) Diversity and movement of indoor Alternaria alternata across the mainland USA. Fungal Genet Biol 81:62-72
Ye SY, Song XL, Liang JL, Zheng SH, Lin Y (2012) Disinfection of airborne spores of Penicillium expansum in cold storage using continuous direct current corona discharge. Biosys Eng 113(2):112-119

Yu J, Jurick WM II, Cao H, Yin Y, Gaskins VL, Losada L et al (2014) Draft genome sequence of Penicillium expansum strain R19, which causes postharvest decay of apple fruit. Genome Announc 2(3): 000635

Zhang MK, Tang J, Huang ZQ, Hu KD, Li YH, Han Z, Chen XY, Hu LY, Yao GF, Zhang H (2018) Reduction of Aspergillus niger virulence in apple fruits by deletion of the catalase gene cpeB. J Agric Food Chem 66:401-5409

Zhang S, Zheng Q, Xu B, Liu J (2019) Identification of the fungal pathogens of postharvest disease on peach fruits and the control mechanisms of Bacillus subtilis JK-14. Toxins 11(6):322

Zhu L, Ni W, Liu S, Cai B, Xing H, Wang S (2017) Transcriptomics analysis of apple leaves in response to Alternaria alternata apple pathotype infection. Front Plant Sci 8:22

Publisher's Note Springer Nature remains neutral with regard to jurisdictional claims in published maps and institutional affiliations. 